This manuscript is a EarthArXiv preprint and has been submitted for publication in the Journal of the Geological Society. Please note that the manuscript has been peer-reviewed but not yet formally accepted for publication. Subsequent versions of this manuscript may, thus, have slightly different content. If accepted, the final version of this manuscript will be available via the 'Peer-reviewed Publication DOI' link on the right-hand side of this webpage. Please feel free to contact any of the authors; we welcome feedback. 


\title{
The enigma of the Albian Gap: spatial variability and the competition between salt expulsion and extension
}

\author{
Leonardo M. Pichel* and Christopher A-L. Jackson \\ Basins Research Group (BRG), Department of Earth Science and Engineering, Imperial College \\ London, South Kensington Campus, SW7 2BP, United Kingdom \\ *I.muniz-pereira@imperial.ac.uk
}

The Albian Gap is a uniquely large (up to $65 \mathrm{~km}$ wide and $>450 \mathrm{~km}$ long), enigmatic salt-related structure in the Santos Basin, offshore Brazil. It is located near the basin margin and trends NE (i.e. sub-parallel to the Brazilian coastline). The gap is characterized by a near-complete absence of Albian strata above depleted Aptian salt. Its most remarkable feature is an equivalently large, equally as enigmatic, basinwarddipping, supra-salt rollover that contains a post-Albian sedimentary succession that is up to $9 \mathrm{~km}$ thick. Due to its unique geometry, size, and counter-regional aspect, the origin and evolution of the Albian Gap has been the centre of debate for $>25$ years. This debate revolves around two competing models; i.e. did it form due to thin-skinned (i.e. supra-salt) extension, or progradational loading and salt expulsion? The extension-driven model states that the Albian Gap (and overlying rollover) formed due to post-Albian gravity-driven extension accommodated by slip on a large, counterregional, listric normal fault (the Cabo Frio Fault). Conversely, the expulsion-driven hypothesis states that the Albian Gap was established earlier, during the Albian, and that post-Albian deformation was controlled by differential loading, vertical subsidence, and basinward salt expulsion in the absence of significant lateral extension. This study utilizes a large (c. 76,000 km), dense (4-8 km line spacing), depth-migrated, 2D seismic dataset that fully covers and thus permits, for the first time, a detailed, quasi-3D structural analysis of the entire Albian Gap. In this study we focus on: i) the evolution of base-salt relief and the original salt thickness variations; and ii) the geometry of the post-Albian rollover, and its related faults and salt structures. To constrain the kinematics of the Albian Gap, and how this relates to the evolution of the base-salt relief, we also apply novel structural restoration workflows that incorporate flexural isostasy, in addition to a detailed, sequential reconstruction of the intra-gap rollover sequences. Our results show that the geometry and kinematics of the Albian Gap vary along-strike, and that both post-Albian extension and expulsion play a 
significant role in its evolution. Basinward-dipping growth wedges, salt rollers, and listric normal faults record extension, whereas sigmoidal wedges, halokinetic sequences, and upturned near-diapir flaps, the latter two associated with large diapirs bounding the downdip edge of the gap, record basinward salt expulsion and inflation. Where the Albian gap is relatively wide $(>50 \mathrm{~km})$, these processes alternate and operate at approximately equal proportions. Our results are consistent with the amount of basinward translation inferred from the analysis of ramp-syncline basins located downdip on the São Paulo Plateau. Our results seemingly reconcile one of the longestrunning debates in salt tectonics, as well as having more general implications for understanding the regional kinematics and dynamics of salt-related structures in other salt basins, in particular the controls on the development of large, counter-regional faults. 


\section{1. Introduction}

2 Salt-bearing passive margins are typified by kinematically-linked domains of updip extension, midslope translation, and downdip contraction and/or salt advance (e.g. Rowan et al., 2004; Peel 2014; Jackson et al., 2015; Jackson and Hudec, 2017). Each of these domains are associated with a complex and variable suite of salt structures. Updip areas of extension are characterized by reactive diapirs, salt rollers, and saltdetached, listric normal faults, whereas downdip areas of contraction are dominated by salt-cored (buckle) folds, thrusts, and actively rising, squeezed diapirs. Intermediate translational domains can have both styles of deformation when developed above variable base-salt relief (Brun and Fort, 2011; Jackson et al., 2015; Dooley et al., 2016; 2018; Pichel et al., 2019b,c). One of the largest and perhaps the most controversial salt structures worldwide is the Albian Gap in the Santos Basin, Brazil. It trends NE, is up to $65 \mathrm{~km}$ wide in its south-central part, and extends sub-parallel to the Brazilian margin for nearly the entire length of the Santos Basin (c. $450 \mathrm{~km}$ long). The gap is located at the boundary between the extensional and translational domains, and is characterized by the near-complete absence of Albian strata and an equally large, up to $55 \mathrm{~km}$ wide, Late Cretaceous-Paleogene counter-regional (i.e. basinward-dipping) rollover that overlies depleted Aptian salt (Fig. 1) (Demercian et al., 1993; Mohriak et al., 1995; Davison et al., 2012; Guerra and Underhill., 2012; Fiduk and Rowan, 2012; Quirk et al., 2012; Jackson et al., 2015).

Due to its unique size, geometry and counter-regional aspect, the Albian Gap has been the centre of debate for $>25$ years (Fig. 2). This debate revolves primarily around its origin and evolution, which have been variably described by either an extension(Fig. 2a) and expulsion-driven model (Fig. 2b). Many authors propose an extension- 
driven origin in which the rollover and the gap itself formed due to post-Albian gravitydriven extension associated with slip on a large, counter-regional, salt-detached normal fault, the Cabo Frio Fault (CFF, fig. 1), which accommodates 30-55 km of lateral displacement (i.e. heave; Fig. 2a) (Cobbold and Szatmari, 1991; Demercian et al., 1993; Mohriak et al., 1995; Davison et al., 2012; Guerra and Underhill., 2012; Rowan and Ratcliff, 2012; Quirk et al., 2012). Others suggest an expulsion-driven origin in which the gap was established earlier, during the Albian, and in which postAlbian deformation was driven by margin progradation and associated differential loading, vertical subsidence, and basinward salt expulsion. These processes together generated the post-Albian expulsion rollover characterising the Albian Gap (Fig. 2b). This model does not require or invoke significant lateral extension or overburden translation (Szatmari et al., 1996; Ge et al., 1997; Gemmer et al., 2005; Krézsek et al 2007; Adam and Krézsek, 2010; Jackson et al., 2015). Cross-section based restorations of the Albian Gap have not yet resolved this debate, as the gap can be reasonably restored either by post-Albian extension (Fig. 2a), or basinward salt expulsion following Albian diapirism (Fig. 2b) (Rowan and Ratliff, 2012; Jackson et al., 2015). In the former model (Fig. 2a), the post-Albian rollover is equivalent to the hangingwall of a counter-regional, salt-detached normal fault, with diapirs and minibasins in its footwall translating basinward for a distance equal to the fault heave. In the latter model (Fig. 2b), the rollover is restored by basinward salt expulsion from a diapir that decreases in width through time, and in which there is no lateral movement of basinward minibasins and associated salt structures.

These two competing hypotheses are intrinsically related to another long-lived controversy, the general salt tectonics and structural evolution of the São Paulo Plateau, a large, basement-cored structural high located immediately downdip of the 
Albian Gap (Fig. 1b). In the extension-driven model, post-Albian extension within the Albian Gap is kinematically balanced by the lateral movement of salt and its overburden on the São Paulo Plateau and downdip contraction of the overburden and/or salt advance via nappe emplacement (Guerra and Underhill, 2012; Fiduk and Rowan, 2012; Quirk et al., 2012; Rowan and Ratliff, 2012). Conversely, in the expulsion-driven model, post-Albian deformation is characterized by salt inflation and intense, intra-salt deformation, but not significant overburden translation and contraction (Ge et al., 1997; Gemmer et al., 2004; Jackson et al., 2015a,b).

Solving these debates is crucial to our understanding of the regional kinematics and geodynamic evolution of not only of the Santos Basin, but also other salt-bearing passive margins. Selecting their appropriate kinematic model will help us geometrically balance basin-scale deformation, and constrain the timing, style, and magnitude of salt movement, deformation, and sub-horizontal translation, the latter typically being problematic due to cryptic diapir shortening and extension (Hossack et al., 1995; Rowan and Ratliff., 2012; Jackson et al., 2015a). Understanding when and how salt and its overburden deforms has important implications for hydrocarbon exploration along salt-bearing margins, given it can help us constrain the location and timing of hydrocarbon migration and trap formation, and the timing of deposition of key petroleum system elements (e.g. source, reservoir, and seal rocks; Jackson et al., 2015; Allen et al., 2016; Pichel et al., 2018). In addition, similar kilometre-scale counter-regional rollovers, geometrically similar to the one in the Santos Basin, are recognized in the northern Gulf of Mexico (Hudec et al., 2019; C. Rodriguez, pers. comm, 2020) and in the Kwanza Basin, offshore Angola (Legeay et al. 2019); in both these locations, the origin of the rollovers is still debated. 
In this study, we present, for the first time, a detailed geometric and kinematic analysis of nearly the entire Albian Gap (Figs. 1 and 3). Whereas most previous studies focused on only one or two, dip-orientated (i.e. NW-trending) cross sections through the centre of the gap where it is widest (Demercian et al., 1993; Mohriak et al., 1995; Ge et al., 1997; Fiduk and Rowan, 2012; Guerra and Underhill, 2012; Jackson et al., 2015), we analyse several dip- and strike-oriented sections to understand its true 3D geometrical and possibly kinematic variability. We use an extensive and modern, 2D depthmigrated seismic dataset (Fig. 1). Small 2D line spacing (4-8 km) provides a dense, quasi-3D grid with which to analyse lateral and vertical variations in base-salt relief, salt and growth strata geometries, and overburden faulting within the Albian Gap. In addition, we restore three cross-sections from different parts of the Albian Gap, focusing on the overlying post-Albian rollover, bounding salt structures, and detachment geometry. By doing this, we are able to constrain the contribution of different mechanisms (i.e. extension and expulsion) to the formation of the gap and, we hope, solve one of the longest-lived controversies in salt tectonics.

\section{Geological Setting}

The Santos Basin covers c. $3.5 \times 10^{5} \mathrm{~km}^{2}$ and is bound by the Cabo Frio High to the northeast and by the Florianopolis Platform to the southwest (Mohriak et al., 1995; Garcia et al., 2012) (Fig. 1a). The basin originated as a rift during the Early Cretaceous in response to the opening of the South Atlantic (Fig.1a-b) (e.g., Meisling et al., 2001; Modica and Brush, 2004; Karner and Gambôa, 2007; Mohriak et al., 2008). Grabens and half-grabens were oriented predominantly NNE-NE due to ESE-SE directed extension and were filled by largely Barremian, fluvial-lacustrine deposits that are overlain by an early-to-middle Aptian, carbonate-dominated succession (Meisling et al., 2001; Davison et al., 2012). The number of active faults and their rate of slip 
decreased during the Aptian and, by the Late-Aptian, a c. 2.5-4 km thick salt succession was deposited (Fig. 1c) (De Freitas, 2006; Davison et al., 2012; Garcia et al., 2012). Salt deposition was controlled by an inherited rift topography, resulting in marked spatial variations in original salt thickness (Davison et al., 2012; Garcia et al., 2012; Rodriguez et al. 2018). In sub-salt lows such as the Merluza Graben (Fig. 1c) (cf. Mohriak et al., 2010), salt was up to c. 4 km thick (Garcia et al., 2012; Lebit et al., 2019). Conversely, on sub-salt highs such as the Outer High (Fig. 1c), salt was only c. $1.5-2 \mathrm{~km}$ thick (Garcia et al., 2012; Rodriguez et al., 2018).

During the early Albian, the Santos Basin experienced fully marine conditions due to thermally induced, post-rift subsidence and a rise in eustatic sea-level (drift stage, Fig. 1b). This resulted in widespread deposition of a carbonate-dominated succession that was up to c. $1 \mathrm{~km}$ thick updip and which thinned basinward to c. $200 \mathrm{~m}$ on the São Paulo Plateau (Fig. 1c) (Modica \& Brush, 2004). During the late Albian, the basin tilted south-eastward, inducing gravity gliding of the salt and its overburden. Salt-related deformation produced numerous thin-skinned, predominantly basinward-dipping, saltdetached normal faults that dismembered the Albian carbonate platform into rafts in the updip extensional domain (zone of extension, fig. 1) (Demercian et al., 1993; Cobbold et al., 1995; Guerra and Underhill, 2012; Quirk et al., 2012). The Albian Gap, the focus of our study, is located at the basinward (i.e. south-eastern) edge of the extensional domain (Fig. 1).

Post-Albian sedimentation was characterized by margin-scale clastic progradation, with sediments derived from the uplifting of the Serra do Mar mountain range (Fig. 1ab) (Modica \& Brush, 2004). Most late Albian faults in the updip extension domain became inactive by the end of the Albian and deformation migrated downdip into the Albian Gap and onto the São Paulo Plateau (SPP) (Fig. 1) (Quirk et al., 2012; Jackson 
et al. 2015a). Post-Albian salt tectonics was characterized by basinward salt evacuation from the Albian Gap, local salt welding (Davison et al., 2012; Jackson et al., $2014 ; 2015 a)$, and up to c. $30 \mathrm{~km}$ of overburden translation further downdip in the São Paulo Plateau (Fig. 1c) (Pichel et al., 2018; 2019c). The base-salt relief and salt thickness variations associated with the inherited rift topography impacted salt tectonics on the São Paulo Plateau, generating flow partition with localized contraction, extension and passive diapirism (Garcia et al., 2012; Pichel et al., 2018; 2019c).

\subsection{Dataset and Methods}

\subsection{Seismic Data and Interpretation}

We use a vast (c. 76,000 km² areal coverage), zero-phased processed, Kirchoff prestack depth-migrated 2D seismic dataset covering nearly the entire length of the Santos Basin and the Albian Gap (Fig. 1). The 2D survey comprises NW- and NEtrending profiles that are oriented sub-parallel to the dip- and strike-direction of the basin (and Albian Gap), respectively (Fig. 1d). Given the size of the Albian Gap, the seismic dataset has a relatively small line spacing (c. $4 \mathrm{~km}$ and $8 \mathrm{~km}$ between dip- and strike-orientated profiles, respectively), giving it a quasi-3D character. Seismic profiles have a total record length of $16 \mathrm{~km}$ and we display images following the Society of Economic Geologists (SEG) normal polarity convention, whereby a downward increase in acoustic impedance is represented by a positive reflection event (white on greyscale seismic sections) and a decrease in acoustic impedance by a negative event (black on greyscale seismic section) (Brown, 2011). The seismic data almost fully images the updip extensional domain and partly images the intermediate translational and minibasin province (cf. Pichel et al., 2018; 2019; Lebit et al 2019), 
intersecting the updip portion of the 3D seismic dataset used by Jackson et al. (2015b) and Pichel et al. (2018; 2019) (Fig. 1).

We mapped base- and top-salt based on their distinct seismic expression and

151

152 overburden geometries (Fig. 3). As we did not have direct access to borehole data, mapping of key post-salt horizons were based on their tectono- and seismicstratigraphic significance, with age-calibration provided by a number of recently published, borehole-constrained cross-sections (Garcia et al., 2012; Guerra and Underhill., 2012; Quirk et al., 2012; Hadler-Jacobsen et al., 2014; Jackson et al., 2015a; Rodriguez et al., 2018). We mapped a Top Albian unconformity (blue) to outline the geometry and extent of the Albian Gap (Fig. 4), and a prominent Paleogene regional unconformity (yellow on figure $1 \mathrm{~b}-\mathrm{c}$ and seismic profiles) that marks the end of bulk salt deformation across most of the basin (cf. Fiduk and Rowan, 2012; Garcia et al., 2012; Guerra and Underhill, 2012; Jackson et al., 2015b). We also mapped key post-Albian (Upper Cretaceous-Paleocene) horizons within the Albian Gap rollover to constrain its present structural style and to infer its evolution via isopach (thickness map) analysis.

\subsection{Restorations}

To restore geometries imaged on seismic reflection profiles we combine decompaction and unfolding by simple vertical shear, and move-on-fault algorithms, following established restoration workflows for salt-related deformation (cf. Rowan and Ratliff 2012). Instead of restoring only a single profile (cf. Ge et al., 1997; Rowan and Ratliff, 2012; Guerra and Underhill, 2012; Jackson et al., 2015), we perform 2D structural restorations of three of the most representative profiles from the Albian Gap. 
171 We restore these profiles to a gently-dipping, clinoform-like seabed that is

172 characteristic of many prograding clastic slopes (cf. Hadler-Jacobsen et al. 2014); by 173 doing this, we incorporate geologically more realistic geometries not applied in 174 previous restorations of the Albian Gap (Fig. 5a). Although commonly gentle (c. $1^{\circ}$ ), 175 the foresets of margin-scale prograding clinoforms can reach up to $16^{\circ}$ (Patruno et al., 176 2015), dipping $0.5-2^{\circ}$ and being c. $50-300 m$ tall in the study-area (see present-day 177 seabed, figs. 6-10). Thus, previous workflows that restored post-Albian rollover horizons to a flat top (cf. Rowan and Ratliff, 2012; Jackson et al., 2015) have likely distorted their original geometries, as well as the gap itself, overestimating the amount of extension. This is seen by differences in geometry, fault heave and throw for the same wedge restored to a flat datum ( $8 \mathrm{~km}$ heave and $3.75 \mathrm{~km}$ throw) or one restored to a gently-dipping seabed (7.4 km heave and $3.6 \mathrm{~km}$ throw) (fig. $5 \mathrm{a})$. We reconstruct the approximate paleo-seabed through time using the present seabed as template and local erosional unconformities and toplaps as additional constraints. Although estimating the bathymetry over time involves some uncertainty, clear stratal terminations in and around the Albian Gap afford confidence in our workflow and, we argue, allows a more accurate representation of growth strata geometries than previous achieved.

Decompaction is performed using the Sclater and Christie (1980) function, assuming a carbonate-dominated (i.e. Albian) and siliciclastic-dominated (i.e. post-Albian) overburden; this assumption is supported by lithological data provided by boreholes 192 (Guerra and Underhill, 2012; Hadler-Jacobsen, 2014). This step is important because it removes the effects of compaction through time, and thereby produces a more accurate visualization of temporal variations in the original rollover geometries, thickness and associated fault throw (Fig. 5b). 
We also incorporate flexural isostatic compensation in each decompaction step to quantify and remove the effects of differential loading and basin subsidence, which ultimately provides more accurate estimates of the base-salt geometry, regional dip, and related salt thickness through time (Fig. 5c). This ultimately permits us to establish the key boundary conditions governing the evolution of the Albian Gap. We use a crustal density of $2.78 \mathrm{~g} / \mathrm{cm}^{3}$ and lithospheric elastic thickness $\left(T_{e}\right)$ of $5 \mathrm{~km}$. We also test $T_{e}$ values of $1.5,10$ and $15 \mathrm{~km}$ but choose $T_{e}=5 \mathrm{~km}$ as we (and others; Scotchman et al., 2006; 2010) argue this is a more valid approximation for highlystretched continental crust; the same value has been applied by other studies focused on the geodynamic evolution of the Santos Basin (Garcia et al., 2012; Rodriguez et al., 2019). We perform a detailed sequential restoration of the central and most representative section within the Albian Gap involving 12 steps from Aptian (top-salt) to present. We then restore additional sections back to the Albian and Aptian; this allows us to constrain spatial variations in the original dimension of the Albian Gap and the original Aptian salt thickness, and the overall basin geometry and depth.

\section{Distinguishing extension from expulsion}

Distinguishing between structural geometries formed by extension vs. salt expulsion is central to determining the processes responsible for the formation of the Albian Gap. As we will argue below, we find evidence for both extension (Fig. 6a) and salt expulsion (Fig. 6b) in the Albian Gap (Figs. 7-9), with the distribution, geometry, and stratigraphic architecture of the related rollover geometries described in the following section (section 5). However, in order to provide a geometric framework within which to interpret our data, we first briefly review the types of rollover geometries produced in physical models of extension- and expulsion-related salt tectonics, as well as those 
identified in natural examples (Fig. 6) (cf. Jackson and Hudec, 2017 and references therein).

222

223

224

We recognize three rollover-related structural styles diagnostic of salt-detached extension: i) salt rollers, ii) salt-detached normal faults and, iii) their associated wedgeshaped growth strata, which thicken towards and are thickest immediately adjacent to the fault and/or flanking diapir (where present) (Figs. 6a and 7-9) (cf. Mauduit et al., 1997; Chimney and Kluth, 2002 Brun and Mauduit, 2009; Jackson and Hudec, 2017). To estimate the amount of extension during deposition of any given sequence, and thus within each time-step in our restorations, we: i) measure fault heave where corresponding footwall and hangingwall cut-offs are unambiguously observed (Figs. 7 and 9); or ii) use the width of their hangingwall growth section (cf. heave in fig. 5a).

In the case of differential loading and basinward salt expulsion, we identify three key rollover-related structural styles: i) sigmoidal wedges that thicken and then thin in the direction of salt expulsion, typically towards and onlapping onto a bounding diapir (Fig. 6b), ii) significant downdip salt inflation, and iii) halokinetic sequences and/or upturned flaps flanking the rollover-bounding diapir (Figs. 7-9). As these expulsion rollovers evolve and underlying salt deflates, older sequences rotate downwards and may not presently be upturned, instead displaying a sigmoidal shape defined by basinward stratal thinning towards a sub-horizontal salt contact (Fig. 6b).

Previous quantitative analysis of the post-Albian rollover in the Albian Gap (cf. Ge et al., 1997; Jackson et al., 2015a) show an asymmetric dip-depth relationship for its growth strata, arguing against a purely extensional origin for the feature, and thus suggesting some contribution of loading-driven, expulsion-related processes. Other studies document c. $28-32 \mathrm{~km}$ of post-Albian basinward translation of salt and overburden within RSBs immediately downdip of the Albian Gap (Pichel et al., 2018), 
also arguing against a purely expulsion origin and therefore indicating also that extensional processes also occurred.

Although presented as end-member types, the dynamic and kinematic models outlined above can operate simultaneously. The stratal thickening associated with extensiondriven rollovers tends to generate differential loading of underlying salt, and greater subsidence and salt expulsion beneath the hangingwalls of their bounding faults. Conversely, expulsion-driven wedges may also accommodate some sub-horizontal extension on secondary normal faults, or against the downdip salt wall, especially when they are deposited above basinward-dipping salt-detachments (sigmoidal wedges offset by older faults in fig. 7, or wedges terminating against small normal faults in Fig. 8). For these reasons, we mapped post-Albian rollover wedges based purely on their large-scale geometry (i.e. sigmoidal vs. basinward-thickening), informed by geometries observed in physical models and other natural examples, but without a preferred kinematic or dynamic model in mind. We then use these geometrical constraints in our cross-sectional restorations to quantify the contribution of extension vs. expulsion to the formation of the Albian Gap. However, given the two end-member processes are intrinsically-linked, there is some error in our estimates (i.e. a period dominated by expulsion includes some extension). Constraining this estimate is hard (i.e. how much extension occurs during a period otherwise dominated by expulsion), although it is clear that the thickness of extension- and expulsion-related wedges is large compared to, for example, the minor amount of fault slip associated with the latter process. We therefore estimate a relatively small error of $\pm 10 \%$ to each restoration step, and to our overall estimate of the contribution of each process.

\section{Albian Gap Structural Framework}


269 The Albian Gap is c. $450 \mathrm{~km}$ long. It varies in width from $10-15 \mathrm{~km}$ in the northeast

270 (North Santos Basin) to 30-50 km in its central portion, widening to $65 \mathrm{~km}$ in its centralsouth portion, before narrowing again to $15 \mathrm{~km}$ to the southwest (Figs. 3-4 and 7-13). The gap is widest (c. 50-65 km) updip of the Sugar-Loaf and Tupi Sub-Highs (cf. Rodriguez et al., 2018; Pichel et al. 2019), and where it is intersected by a large NNESSW-striking basement-involved fault (i.e. the Merluza Fault, Mohriak et al., 2011) in the southwest (Figs. 3-4). The gap is associated with a post-Albian, basinward-dipping rollover that is of equivalent length, $6-10 \mathrm{~km}$ thick (Fig. 14a), and up to $55 \mathrm{~km}$ wide (Fig. 7). This rollover overlies salt that is strongly depleted or apparently welded (Fig. 14b). The salt layer ranges from nearly welded in places ( $<50 \mathrm{~m}$ thick) to an average of $100 \mathrm{~m}$ thick and up to $500 \mathrm{~m}$ thick salt rollers (Figs. 7-13 and 14b).

\subsection{Salt and Fault Geometries}

Counter to that previously described, the Albian Gap is not defined on its basinward edge by a single, through-going (i.e. c. $450 \mathrm{~km}$ long), landward-dipping listric fault (Cabo Frio Fault, cf. Mohriak et al., 1995; Guerra and Underhill, 2012; Fiduk and Rowan, 2012; Quirk et al., 2012). It is instead bound by a series of smaller $(4-12 \mathrm{~km}$ long) fault segments and associated salt rollers (Figs. 7-12). Salt rollers occur within or defining the outboard margin of the Albian Gap ( $R$ in figs. 7-12). The ones within the gap are relatively small (200-500 m tall on average) (Figs. 7-9), although some are up to $1.2 \mathrm{~km}$ tall (Fig. 13). Rollers bounding the basinward side of the gap are larger (1-1.5 km tall) than those within the gap but occur only in the northern and southern sectors of the structure (Figs. 11-12). These rollers are broadly asymmetric and triangular in shape, and are commonly defined on their landward sides by landwarddipping listric normal faults (Figs. 7-10), although basinward-dipping faults also occur in the north (Fig. 11) and south of the gap (Fig. 12). In some cases, both sides of the 
salt rollers are flanked by different-age packages of wedge-shaped strata that towards

295

296

297

298

299

300

301

302

303

304

305

306

307

308

309

310

311

312

313

314

315

316

317

318

them. Such geometries have been described by Quirk and Pilcher (2012), who argue they document a temporal switch in fault polarity from one diapir flank to the other (Figs. 11-12) (so-called "flip-flop salt tectonics"; Quirk and Pilcher., 2012).

The dominant landward-dipping faults contain $0.4-1 \mathrm{~km}$ thick, basinward-thickening wedges in their hangingwall. Equivalent-age strata are thin or absent on their footwalls (Figs 7-8). Where strata are missing, we estimate fault heaves of c. 2-6 km using the width of their hangingwall growth wedges. Salt rollers and faults generally become younger, larger, and display greater displacement basinward as indicated by their progressively younger growth strata and their shallower tip heights (Figs. 7-10). This indicates that extension migrated basinward.

The basinward limit of the Albian Gap is, therefore, commonly defined by a partiallyto-fully fault-bounded diapir (Figs. 7-8). Where the gap is relatively narrow $(<30 \mathrm{~km})$, the diapir is asymmetric and triangular in cross-section, a geometry characteristic of reactive (i.e. extensional) diapirs and/or salt rollers (cf. Vendeville and Jackson, 1992; Jackson and Hudec, 2017) (Figs. 10-11). However, in the central portion of the gap, where it is relatively wide ( $>30 \mathrm{~km})$ (Fig. 7-9 and 12), the geometry and size of the bounding diapir are markedly different and cannot be entirely explained by post-Albian extension. In this location the diapirs are irregular and semi-circular in plan-view, rather than linear like those seen to the north and south where extension dominates (Figs. $3 \mathrm{~b}$ and $14 \mathrm{~b}$ ). The diapirs are $8-12 \mathrm{~km}$ wide, up to $4 \mathrm{~km}$ tall, and are partially defined by a landward-dipping listric fault on their landward margins (Figs. 7-8). Locally upturned and thinned strata are also observed near the tops of the diapirs on their landward margins. In contrast, their basinward margins are always flanked by locally upturned and thinned strata (Figs. 7-8). In other cases, the diapirs are narrower (2-4 
$\mathrm{km}$ wide), taller (>4.5 km) and have upturned and thinned strata on both of its flanks with no evidence of extension (Fig. 9). This upturned strata can vary from km-scale, so-called composite halokinetic sequences (i.e. CHSs) (cf. Giles and Rowan 2012; Pichel and Jackson 2020) or multi-km upturned flaps (cf. 'megaflaps' of Rowan et al. 2016) (Fig. 15). Larger flaps are more common on the basinward flanks of the gapbounding diapirs, whereas CHSs typically occur on their landward sides, within the Albian Gap.

Both cases indicate that the diapirs bounding the central and widest portion of the Albian Gap were largely influenced (Figs. 7-8) and, in places (Fig. 9), driven by a combination of passive and active salt rise. Active and especially passive rise are loaddriven processes and can thus occur in the absence of extension (Rowan et al., 2003; Jackson and Hudec, 2017). However, bounding diapirs experienced an early phase of reactive, extension-driven rise, as indicated by the presence of rollover strata thickening towards listric normal faults flanking their lower, landward flanks (Figs. 78).

\subsection{Rollover Geometries}

In addition to the intra- and gap-bounding diapirs, the post-Albian rollover geometries also vary in terms of their geometry and origin (Figs. 7-9). They can be characterized by i) basinward-thickening wedges that expand towards landward-dipping, saltdetached (listric) normal faults (Figs. 7-10); or ii) sigmoidal wedges that are thicker in their centre, but which thin and downlap basinward towards the salt, onto 'stranded', intra-gap Albian blocks or the footwalls of salt rollers (Figs. 7-9).

Whereas the first geometry is readily linked to regional gravity-driven extension (Fig. 6a) (cf. Brun and Mauduit, 1997; Rowan et al., 1999; Jackson and Hudec, 2017), the 
second cannot be explained by the same process (Fig. 6b) (see section 4). Besides, similar sigmoidal, basinward-dipping and -thinning wedges occur landward of the Albian Gap where they clearly downlap the Albian interval (Fig. 8); this geometry cannot be readily explained by slip on a normal fault or, therefore, record extension. We interpret that these sigmoidal geometries are associated with prograding clinoforms that were later rotated by the deflation and basinward expulsion of salt (Fig. 6b) (cf. Ge et al., 1997; Jackson and Hudec, 2017). They occur predominantly in the central-south portion of the Albian gap where it is widest (>35 km, figs. $7-9)$. We make the key observations that the wider the gap, the more abundant are the sigmoidal wedges, and the larger is the basinward-bounding diapir (Figs. 7-8).

The Albian Gap lies downdip of the Serra do Mar mountain range (Fig. 1), which formed during the Late Cretaceous-Eocene, coeval with the formation of the Albian Gap rollover (Mohriak et al., 1995; Guerra and Underhill, 2012). Continental uplift resulted in erosion and basinward progradation clastic sediments into the Albian Gap landward and salt-detached extension is controlled by landward-dipping normal faults that are antithetic to the overall basinward direction of gravity-driven transport (Figs. 
6-9). At its south and north portions, however, this changes. In its northern portion where it narrows abruptly to $<14 \mathrm{~km}$, the gap is bound by a flip-flop roller and a basinward-dipping normal fault (Fig. 11). In its southernmost portion, basinward of a major pre-salt rift structure, the Merluza Graben, the Albian Gap is bound on its basinward side by basinward-dipping, salt-detached normal faults (Fig. 12). The Merluza Fault has a throw of $3.5 \mathrm{~km}$ at the base-salt and is associated with the largest diapir (c. $8.5 \mathrm{~km}$ tall and $10 \mathrm{~km}$ wide) within the study-area (and possibly the entire basin, Fig. 3b). This suggests that the graben was a major structural low prior to and during (and possibly after) salt deposition, resulting in initially locally thickened salt (c. 2.5-4 km thick). Other small, landward-dipping, basement-involved sub-salt faults produced $0.5-1 \mathrm{~km}$ of structural relief at the base-salt and, thus, contribute to a regionally rugose base-salt beneath the Albian Gap (Figs. 3a and 7-10).

The thicker succession of Aptian salt within the Merluza Graben resulted in: i) partition of salt flow with increased diapiric rise updip of the Albian Gap and, ii) a locally steeper, basinward-dipping base-salt within the Albian Gap due to tilting of the footwall of the Merluza Fault. The large (c. $10 \mathrm{~km}$ wide) diapir near the south-eastern edge of the Merluza Graben produced an additional c. $10 \mathrm{~km}$ of separation of the Albian interval given the diapir was growing during the Albian (i.e. Albian strata were not deposited above it). Further basinward, the steeper basinward-dipping base-salt influenced the style of salt-detached faulting here, which is predominantly synthetic (i.e. basinwarddipping) and in marked contrast to other areas of the Albian Gap.

\section{Restoration}

\subsection{Kinematics on a salt-detached slope}


391 Previous structural restorations of the Albian Gap were ambiguous, meaning that the 392 Albian Gap could be restored by purely salt expulsion and vertical subsidence 393 (expulsion-model), or regional extension (extension-model) (Rowan and Ratliff, 2012; Jackson et al. 2015). This ambiguity is at least partly due to the fact these restorations: i) have not incorporated the variable rollover stratal geometries (i.e. sigmoidal clinoforms associated with margin progradation vs. basinward-thickening wedges associated with fault slip), ii) incrementally restored the rollover succession to a flattop, distorting the original (i.e. syn-depositional) stratal geometries, iii) have not included the effects of flexural isostasy, keeping the base-salt static through time, iv) did not incorporate kinematic constraints provided by structural geometries seen immediately downdip on the São Paulo Plateau. Here we present for the first time, a detailed sequential restoration of the Albian Gap incorporating these aspects (Fig. 17). In the main restored section (Fig. 8), centrally located within the Albian Gap, the gap is presently c. $50 \mathrm{~km}$ wide. The cumulative heave on faults flanked by basinwardthickening, fault slip-related wedges documents c. $26 \mathrm{~km}$ of post-Albian extension (Fig. $17 a-I)$. This is equivalent to c. $50 \%$ of the current width of the gap, demonstrating that by Albian times the gap was already there in the form of a c. $24 \mathrm{~km}$ wide, c. $2.8 \mathrm{~km}$ tall, and 90-100 km long reactive/passive diapir (Fig. 17m). Early post-Albian sequences $(g, h, j$ and $\mathrm{l})$ were primarily associated with basinward progradation of the basin margin by clinoform accretion (Figs. 7-9), and vertical subsidence due to salt thinning and lateral expulsion. Overlying sequences were predominantly affected by sub-horizontal extension of the overburden (a-f and i; Fig. 17). The restorations also demonstrate that extension-dominated wedges commonly involve a secondary component of differential loading and basinward salt expulsion due to hangingwall stratal thickening (i.e. note progressive salt thinning beneath extensional wedges; fig. 
416 17b-f). Conversely, some sigmoidal, expulsion-dominated wedges also demonstrate

417 a small amount (c. 1-2 km) of extension against the downdip salt wall (Fig. $17 \mathrm{~g}$ ) or, more commonly, due to ongoing slip on a previously formed fault (Fig. 17h).

Additional restored sections in the central portion of the Albian Gap show that postAlbian extension varied from $26-28 \mathrm{~km}( \pm 2 \mathrm{~km})$ (Figs. 18 and 19). All restorations show that where it is presently widest, the gap was already partly formed during the Albian in the form of a 24-30 km wide passive diapir (Figs. 17 and 18); this diapir was initially narrower $(<2 \mathrm{~km})$ and, likely reactive where the gap is presently narrower $(<30$ km, fig. 19). Our restorations show that the variable present width of the Albian Gap was primarily controlled by the original width of the gap during the Albian (i.e. Albian diapir). They also show that post-Albian extension in the central portion of the Albian Gap (figs. 7-10) showed little along-strike variability $(26-28 \mathrm{~km}$, according to our restorations; figs. 17-19). Extension nonetheless varied laterally throughout the full length of the Albian Gap, being as little as $10-12 \mathrm{~km}$ in the northernmost portion where the gap is presently narrower (Fig. 12). Our measurements of extension agree with estimates of $28-32 \mathrm{~km}$ of post-Albian translation of salt and overburden obtained from the analysis of ramp-syncline basins downdip on the São Paulo Plateau (Pichel et al., 2018). We argue that area was kinematically linked to the Albian Gap, being equivalent to its (mega)footwall.

\subsection{Loading and Flexural Isostasy}

Flexural isostasy is associated with the long-wavelength effects driven by the isostatic response of the crust to sediment loading (e.g. Roberts et al., 1998; Scotchman et al., 2008; Garcia et al., 2012). Flexural isostasy assumes that any load on the lithosphere is supported by flexural bending stresses within the immediate area surrounding the load. Applying flexural isostasy to structural restorations has been shown to yield the 
most geologically realistic results in backstripping workflows (Roberts et al., 1998;

Scotchman et al., 2008). In the Santos Basin, the base-salt beneath and near the

Albian Gap presently dips $0.5-1.5^{\circ}$ landward for at least $150 \mathrm{~km}$ in the dip direction

(Figs. 7-11), with the exception being the more strongly basinward-dipping footwall of

445

446

447

448

449

450

451

452

453

454

455

456

457

458

459

460

461

462

463

464

465 the Merluza Fault in the south (section 5.3, fig. 12). This is anomalous when compared to the majority of passive margin salt basins such as in Campos and Espirito Santo basins, offshore Brazil (Mohriak et al., 2012; Davison et al., 2012; Dooley et al. 2016), West and Northwest Africa (Marton et al., 2000; Tari et al., 2003; 2012; Hudec and Jackson, 2004; Peel 2014; Pichel et al., 2019), and the Gulf of Mexico (Rowan et al., 2004; Hudec et al., 2018), where the detachment presently dips regionally basinward.

Our restorations show that this somewhat unusual, landward-dipping attitude of the salt detachment in the Santos Basin relates to the presence of the equally enigmatic and large (450 km long, up to $55 \mathrm{~km}$ wide and $10 \mathrm{~km}$ thick), post-Albian rollover associated with the Albian Gap (Figs. 7-8). The restorations also demonstrate that the base-salt originally dipped basinward $1.2-1.5^{\circ}$ (on average) and that it switched polarity progressively through time due to proximal loading by the thick, post-Albian sequence now overlying and filling the Albian Gap (Figs. 17-19). The landward dip of the base-salt was, nonetheless, established relatively early, during deposition of the two lowermost post-Albian sequences (Fig. 18). Deposition and thus isostatic loading were focused within the Albian Gap as salt was being expelled from underneath it. Salt expulsion and diapir growth basinward of the gap generated a barrier that hindered the basinward transport of sediment (cf. Modica and Brush, 2004; Hadler-Jacobsen, 2014).

Our restorations also show that the original salt thickness was $0.8-1.2 \mathrm{~km}$ over presalt highs, 1-2 km in the Albian Gap, and 1.4-2.8 km further downdip and over pre-salt 
lows (Figs. 17-19). Although involving a degree of uncertainty due to, for example, the out-of-plane movement of salt (cf. Rowan and Ratliff, 2012), our top-salt restorations are based on, we argue, valid assumptions that the salt was in depositional connection across pre-salt highs and that unfolding to a gently $\left(<0.5^{\circ}\right)$ basinward-dipping regional datum is permissible (see Hudec and Norton, 2019; Hudec et al., 2019). Our measured depositional salt thicknesses are consistent with the estimates of Davison et al. (2012), Garcia et al. (2012), and Rodriguez et al. (2018).

\section{Discussion}

\subsection{Albian Gap kinematics: expulsion vs. extension}

We identified three geometries evidence for gravity-driven, salt-detached, post-Albian extension within the Albian Gap. These are: i) salt rollers, ii) listric normal faults; iii) basinward-thickening wedges. Moreover, ramp-syncline basins that indicate $28-32 \mathrm{~km}$ of salt-detached basinward translation on the São Paulo Plateau downdip of the Albian Gap (cf. Pichel et al., 2018) are another diagnostic of equivalent gravity-driven extension within the Albian Gap as seen from the restorations (Figs. 17-19).

Despite the aforementioned evidence for extension, the sum of observed heaves $(<30$ $\mathrm{km}$ ) on individual salt-detached normal faults and stratal separations associated with related salt rollers cannot account for the entire separation of the Albian interval where the gap is $>30 \mathrm{~km}$ wide (Figs. 7-9). Moreover, contrasting diapir and related growth strata geometries suggest an additional control on its evolution. Three other observations suggest that post-Albian basinward salt expulsion also played a significant role in the formation of the Albian Gap: i) basinward-thinning sigmoidal wedges that downlap onto deflated salt and/or remnant (i.e. intra-gap) Albian blocks; ii) bounding diapirism and salt inflation; and iii) halokinetic sequences or upturned 
flaps. These features are all driven by vertical subsidence and differential loading, forming completely independent of extension.

\subsection{Albian Gap Model}

We have argued that the Albian Gap was formed by a combination of thin-skinned extension and salt expulsion (i.e. differential loading), with these processes operating in approximately equal proportions during post-Albian times where the gap is widest (c. $50-60 \mathrm{~km}$ ). This is equivalent to c. $25-30 \mathrm{~km}$ of post-Albian extension in its central portion, which balances the amount of post-Albian translation recorded in rampsyncline basins further basinward on the São Paulo Plateau (28-32 km of translation; Pichel et al., 2018). We therefore propose a revised, hybrid model for the Albian Gap in which we combine both processes (Fig. 20).

In our model, the gap was formed by: i) post-Albian salt expulsion due to basinward progradation of a basin margin-attached clastic wedge and differential loading of an Albian salt wall; the timing and location of sediment input was coeval with and likely controlled by uplift of the adjacent Serra do Mar (cf. Modica and Brush, 2004), and ii) broadly coeval extension related to basinward translation and stretching of overburden above a salt detachment that initially dipped basinward due to post-rift thermal subsidence (cf. Quirk et al., 2012) (Fig. 20). Post-Albian basinward translation of salt and overburden occurred downdip (footwall) of the Albian Gap, whereas within the gap (hangingwall) only the salt translated basinward. The blocks further landward of the Albian Gap did not move laterally as, by that time, Aptian salt was locally welded and the base-salt had flipped to dip landward due to isostatic loading by post-Albian clastic sediments (Fig. 20). This model explains why the gap is wider in its southcentral portion as a result of greater post-Albian salt mobilization basinward, a process ultimately driven by: 1) greater local salt supply related to the presence of an initially 
515 volumetrically larger, Albian salt wall, and 2) greater basinward progradation of post-

516 Albian clastic sediments.

517 Our model is analogous to the 'heel-keel model' (cf. Krézsek et al., 2007; Jackson and 518 Hudec, 2017) where there is a switch from early basinward-dipping faulting to later 519 landward-dipping fault. In our case, during the Albian, extension was accommodated 520 primarily by basinward-dipping listric faults (Fig. 20b). Continuous sedimentary loading in their hangingwalls drove salt withdrawal, increasing basal drag and ultimately stopping the associated thin-skinned deformation (cf. Krézsek et al., 2007). Salt expulsion from their hangingwalls resulted in salt inflation and a large diapir then formed further downdip; this diapir acted as topographic high above which no Albian sediments were deposited (Fig. 20b). This area was then able to move faster than the updip depleted salt segment. This resulted in additional 26-28 km (Figs. 17-19) of separation of the Albian interval due to post-Albian progradation above the thicker, more mobile salt, and the development of counter-regional faults (Fig. 20c-d). Our estimates of salt-detached extension are fairly consistent in the central part of the Albian Gap (26-28 km; Fig. 17-19), but decrease north-eastwards (c. 10-14 km; Fig. 11) and south-westward (c. 5-6 km) (Fig. 3). The evidence for expulsion (i.e. sigmoidal wedges, near-diapir upturned strata, and major salt inflation) also decreases away from the gap centre (Figs. 10-12), suggesting that this process becomes secondary, likely as a consequence of less margin progradation and related salt loading (Fig. 16) and an initially narrower or absent precursor (i.e. Albian) diapir.

These counter-regional faults have thin, tabular successions in their footwalls; in some cases, strata age-equivalent to that observed in their hangingwalls are locally absent, meaning that their footwall is mostly formed by younger hangingwall growth strata of a basinward fault (Figs. 7-9). This suggests that these faults formed over inflated salt 
lacking pre-extension Albian sediments and that their footwall was primarily composed of salt expelled from beneath their adjacent hangingwalls (Fig. 20b-c). In other words, the Albian was not deposited uniformly within the study-area and that, by the beginning of the Late Cretaceous, the Albian Gap was already partially present in the form of a 20-30 km wide passive diapir (Fig. 20; see also restorations in Fig. 17-18). This initial diapiric gap could be explained by a combination of reactive and passive salt rise during the Albian (see Jackson et al., 2015). The additional 25-30 km of separation of the Albian interval was subsequently accommodated by post-Albian extension. This resulted in the basinward expulsion of salt from within this Albian diapir onto the São Paulo Plateau, where salt inflation and $28-32 \mathrm{~km}$ of translation are observed (Figs. 1720) (c.f. Jackson et al., 2015; Pichel et al., 2019c).

In gravity-driven systems, downdip salt flow over a basinward-dipping detachment typically results in the extension being preferentially accommodated by synthetic (i.e. basinward-dipping) normal faults (Brun and Fort, 2011; Quirk et al., 2012; Jackson and Hudec, 2017). Why was post-Albian extension along most of the extensional domain in the Santos Basin largely accommodated on counter-regional, landwarddipping normal faults? Three possible hypotheses may explain this:

1) Progressive dip reversal of the salt detachment driven by flexural isostasy

2) Inherited base-salt relief associated with pre-salt rift faults

3) Rapid margin-scale progradation above thick salt and salt expulsion basinward

The anomalous counter-regional dip of the salt detachment within the Albian Gap likely

562 influenced the style and polarity of overburden faulting, locally favouring antithetic basal-shear and counter-regional faulting (cf. Brun and Mauduit 2009). However, as 
seen from our restorations, which explicitly account for flexural isostasy, the detachment originally dipped basinward so that the early development of counterregional faults and basinward-dipping rollover was not controlled by the detachment dip. The flip in base-salt polarity may, nonetheless, have favoured the development of larger counter-regional faults later in the history of the Albian Gap, after a significantly thick overburden succession was deposited within it (Figs. 7-10).

The several, predominantly landward-dipping base-salt steps associated with earlierformed rift normal faults produced a rugose base-salt that likely influenced the location and style of supra-salt faulting, as well as local salt rise in the Albian Gap. The nucleation of salt and supra-salt structures by rift-related base-salt topography is demonstrated in several studies (Ge et al., 1997; Adam and Krézsek, 2010; Dooley et al., 2016; 2018; Pichel et a., 2019a,b,c). The base-salt steps within the Albian Gap may have disturbed net-basinward salt flow, favouring the development of listric normal faults and salt rollers with the same polarity to the underlying, base-salt relief that is dominated by landward-dipping steps (Figs. 7-9). However, given that counterregional faults also appear above areas with a locally flat base-salt (Figs. 8 and 10), this effect appears to be secondary.

Physical models of salt-detached rollovers have shown that high-sedimentation rates favour the development of counter-regional (i.e. landward-dipping) faults (Krézsek et al., 2007). Prograding margins, such as the Santos Basin, have typically high rates of accommodation generation and sediment input (Modica and Brush, 2004; HadlerJacobsen et al., 2014). In the Albian Gap, an anomalously thick (> $9 \mathrm{~km}$ ) overburden was deposited directly above thick $(1.5-2 \mathrm{~km})$ salt during the Late CretaceousPaleogene; this was associated with rapid progradation and hinterland uplift in the Serra do Mar (Fig. 1). 
We propose that the three mechanisms outlined above jointly influenced the geometry and kinematics of the Albian Gap. However, we suspect that the main control on the development of basinward-dipping rollovers and counter-regional faults and, therefore, the key driver for extension within the Albian Gap was differential loading associated with progradation above thick, inflated salt (Fig. 20). This resulted in salt being expelled basinward from beneath prograding clinoforms and from the earlierformed diapir, up onto the footwall of counter-regional faults (Figs. 17 and 20).

\section{Conclusions}

Our study provides the first ever quantification of the contribution between the two competing processes generating the Albian Gap, expulsion vs extension. This is based on systematic analysis of the post-Albian rollover spatial variability and contrasting growth strata geometries, i.e. basinward-thickening strata vs. sigmoidal clinoform wedges, distribution of normal faults, and different styles of diapirism. We identify evidence for post-Albian salt-detached extension as well as evidence for salt expulsion driven by differential loading within the Albian Gap. This shows that neither pure post-Albian salt expulsion or extension can fully account for the entire separation of the Albian interval, nor the observed rollover and diapir geometries within the Albian Gap.

We also applied a novel structural restoration methodology that, for the first time, combines decompaction, flexural isostasy, and unfolding of margin-scale rollover geometries to a gently-dipping seafloor. This allowed us to provide detailed structural restorations of key sections and to present more accurate estimates of how overburden extension, vertical subsidence, base-salt geometry, and salt and overburden thickness, varied through time. Moreover, we incorporate the contrasting Albian Gap rollover geometries and measurements of overburden translation from the 
adjacent São Paulo Plateau as kinematic constraints. We then propose a new model based on the seismic observations and structural restorations that demonstrates that the Albian Gap was formed by a combination of post-Albian extension and salt expulsion at approximately equal proportions where the gap is wider (>50 km). In this model, the gap was already partially established during the Albian as a 20-30 wide salt wall. Additional $25-30 \mathrm{~km}$ of extension occurred during the post-Albian driven by margin-scale progradation of sediments over an inflated salt wall, promoting differential loading and salt expulsion basinward onto the São Paulo Plateau. The extension was therefore controlled by differential loading and expulsion of salt basinward, which, coupled with the gradual base-salt dip reversal and presence of base-salt steps favoured the development of counter-regional faults. This work not only specifically contributes to the long-lived debate of the origin of the Albian Gap, but also to our more general understanding of the controls on the development of driven salt deformation that can be applied to many worldwide salt basins.

\section{Acknowledgements}

631 First, we thank TGS and WesternGeco as well as individuals in these companies, in special Kerly Sanchez and Emmi Vargas for granting permission to use seismic data. We also thank Schlumberger for academic licenses of Petrel and Petex for Move. We thank also Mar Moragas and Mike Hudec for the very detailed and constructive reviews that greatly contributed to improve this paper, as well Giovanni Camanni for the editorial handling. We thank Craig Magee for providing a bathymetric map for figure one. We are also very grateful 637 for discussions with Frank Peel, Olly Duffy, Gillian Apps and Mark Rowan which significantly helped developing the concepts behind this paper. 
Allen, H., Jackson, C. A-L., Fraser, A. J. (2016). Gravity-driven deformation of a youthful saline giant: the interplay between gliding and spreading in the Messinian basins of the Eastern Mediterranean. Petroleum Geoscience, 22(4), 340-356. Brown, A. R. (2011). Interpretation of three-dimensional seismic data. Society of Exploration Geophysicists and American Association of Petroleum Geologists.

Brun, J. P., Fort, X. (2011). Salt tectonics at passive margins: Geology versus models. Marine and Petroleum Geology, 28(6), 1123-1145

Cobbold, P. R., Szatmari, P., Demercian, L. S., Coelho, D., Rossello, E. A. (1995). Seismic and experimental evidence for thin-skinned horizontal shortening by convergent radial gliding on evaporites, deep-water Santos Basin, Brazil, in: Jackson, M. P. A., Roberts, D. G., Snelson, S. (eds) Salt tectonics: a global perspective. AAPG Memoir 65, 305-321.

652

Demercian, S., Szatmari, P., Cobbold, P. R. (1993). Style and pattern of salt diapirs due to thin-skinned gravitational gliding, Campos and Santos basins, offshore Brazil. Tectonophysics, 228(3-4), 393-433.

Davison, I., Anderson, L., Nuttall, P. (2012). Salt deposition, loading and gravity drainage in the Campos and Santos salt basins. Geological Society of London Special Publications, 363(1), 159-174.

Dooley, T. P., Hudec, M. R., Carruthers, D., Jackson, M. P., Luo, G. (2016). The effects of base-salt relief on salt flow and suprasalt deformation patterns-Part 1: Flow across simple steps in the base of salt. Interpretation, 5(1), SD1-SD23.

661 Dooley, T. P., Hudec, M. R. (2016). The effects of base-salt relief on salt flow and 662 suprasalt deformation patterns-Part 2: Application to the eastern Gulf of Mexico. Interpretation, 5(1), SD25-SD38.

664 Dooley, T. P., Hudec, M. R., Pichel, L. M., Jackson, M. P. (2018). The impact of base665 salt relief on salt flow and suprasalt deformation patterns at the autochthonous, 666 paraautochthonous and allochthonous level: insights from physical models. 667 Geological Society, London, Special Publications, 476, SP476-13. 
668 Fiduk, J. C., Rowan, M. G. (2012). Analysis of folding and deformation within layered

669

670

671

672

673

674

675

676

677

678

679

680

681

682

683

684

685

686

687

688

689

690

691

692

693

694

695

evaporites in Blocks BM-S-8 \&-9, Santos Basin, Brazil. Geological Society, London, Special Publications, 363(1), 471-487.

Garcia, S. F., Letouzey, J., Rudkiewicz, J. L., Danderfer Filho, A., \& de Lamotte, D. F. (2012). Structural modeling based on sequential restoration of gravitational salt deformation in the Santos Basin (Brazil). Marine and Petroleum Geology, 35(1), 337353.

Ge, H., Jackson, M. P., Vendeville, B. C. (1997). Kinematics and dynamics of salt tectonics driven by progradation. AAPG bulletin, 81(3), 398-423.

Gemmer, L., Ings, S.J., Medvedev, S. Beaumont, C. (2004). Salt tectonics driven by differential sediment loading: stability analysis and finite-element experiments. Basin Research, 16(2), 199-218.

Giles, K. A., \& Rowan, M. G. (2012). Concepts in halokinetic-sequence deformation and stratigraphy. Geological Society, London, Special Publications, 363(1), 7-31.

Guerra, M. C., Underhill, J. R. (2012). Role of halokinesis in controlling structural styles and sediment dispersal in the Santos Basin, offshore Brazil. Geological Society, London, Special Publications, 363(1), 175-206.

Hadler-Jacobsen, F., Groth, A., Hearn, R.E., and Liestøl, F.M. (2010), Controls on and expressions of submarine fan genesis within a high accommodation margin setting,

Santos Basin, Brazil-A high-resolution seismic stratigraphic and geomorphic case study, in Wood, L.J., Simo, T.T., and Rosen, N.C., eds., Seismic Imaging of Depositional and Geomorphic Systems: Gulf Coast Section Society for Sedimentary Geology Foundation Annual Bob F. Perkins Research Conference Proceedings, v. 30, p. 572-615.

Hossack, J. (1995). Geometric rules of section balancing for salt structures.

Hudec, M. R., Jackson, M. P. A. (2004). Regional restoration across the Kwanza Basin, Angola: Salt tectonics triggered by repeated uplift of a metastable passive margin. AAPG bulletin, 88(7), 971-990. 
Hudec, M. R., \& Norton, I. O. (2019). Upper Jurassic structure and evolution of the 697 Yucatán and Campeche subbasins, southern Gulf of Mexico. AAPG Bulletin, 103(5), 1133-1151.

Hudec, M. R., Dooley, T. P., Peel, F. J., \& Soto, J. I. (2019). Controls on the evolution of passive-margin salt basins: Structure and evolution of the Salina del Bravo region, northeastern Mexico. Geological Society of America Bulletin. Jackson, M.P., Hudec, M.R. (2017). Salt Tectonics: Principles and Practice. Cambridge University Press.

704

Jackson, C. A. L., Jackson, M. P., Hudec, M. R. (2015a). Understanding the kinematics of salt-bearing passive margins: A critical test of competing hypotheses for the origin of the Albian Gap, Santos Basin, offshore Brazil. Geological Society of America Bulletin, 127(11-12), 1730-1751.

Jackson, C. A. L., Jackson, M. P., Hudec, M. R., Rodriguez, C. R. (2015b). Enigmatic structures within salt walls of the Santos Basin-Part 1: Geometry and kinematics from 3D seismic reflection and well data. Journal of Structural Geology, 75, 135-162.

Karner, G. D., Gambôa, L. A. P. (2007). Timing and origin of the South Atlantic presalt sag basins and their capping evaporites. Geological Society, London, Special Publications, 285(1), 15-35.

Krézsek, C., Adam, J. and Grujic, D (2007). Mechanics of fault and expulsion rollover systems developed on passive margins detached on salt: insights from analogue modelling and optical strain monitoring. Geological Society, London, Special Publications, 292(1), pp.103-121.

Lebit, H., Arasanipalai S., Tilton, J. \& Ollagnon, P. (2019) Santos Vision: Innovative Seismic Data Processing in a Super Giant Oil Basin. GeoExPro, May, 2019.

Marton, G., Tari, G. Lehmann, C (1998). Evolution of salt-related structures and their impact on the post-salt petroleum systems of the Lower Congo Basin, offshore Angola. In: American Association of Petroleum Geologists International Conference and Exhibition, Rio de Janeiro. Extended Abstracts Volume, 834-834. 
Meisling, K. E., Cobbold, P. R., Mount, V. S. (2001). Segmentation of an obliquely rifted margin, Campos and Santos basins, southeastern Brazil. AAPG bulletin, 85(11), 1903-1924.

Modica, C. J., Brush, E. R., 2004. Postrift sequence stratigraphy, paleogeography, and fill history of the deep-water Santos Basin, offshore southeast Brazil. AAPG bulletin, 88(7), 923-945.

Mohriak, W.U., Macedo, J.M., Castellani, R.T., Rangel, H.D., Barros, A.Z.N., Latgé, M.A.L., Mizusaki, A.M.P., Szatmari, P., Demercian, L.S., Rizzo, J.G. Aires, J.R. (1995). Salt tectonics and structural styles in the deep-water province of the Cabo Frio region, Rio de Janeiro, Brazil, in: Jackson, M. P. A., Roberts, D. G., Snelson, S. (eds) Salt tectonics: a global perspective. AAPG Memoir 65, 273-304.

Mohriak, W., Nemčok, M., Enciso, G. (2008). South Atlantic divergent margin evolution: rift-border uplift and salt tectonics in the basins of SE Brazil. Geological Society, London, Special Publications, 294(1), 365-398.

Mohriak, W. U., Nóbrega, M., Odegard, M. E., Gomes, B. S., \& Dickson, W. G. (2010). Geological and geophysical interpretation of the Rio Grande Rise, south-eastern Brazilian margin: extensional tectonics and rifting of continental and oceanic crusts.

Mohriak, W. U., Szatmari, P., Anjos, S. (2012). Salt: geology and tectonics of selected Brazilian basins in their global context. Geological Society, London, Special Publications, 363(1), 131-158.

Patruno, S., Hampson, G. J., \& Jackson, C. A. (2015). Quantitative characterisation of deltaic and subaqueous clinoforms. Earth-Science Reviews, 142, 79-119.

Peel, F. J. (2014). The engines of gravity-driven movement on passive margins: Quantifying the relative contribution of spreading vs. gravity sliding mechanisms. Tectonophysics, 633, 126-142.

Pichel, L. M., Peel, F., Jackson, C.A.-L., Huuse, M., 2018, Geometry and kinematics of salt-detached ramp syncline basins, Journal of Structural Geology, 115, 208-230. in press, doi: 10.1016/j.jsg.2018.07.016. 
752 Pichel, L. M., Huuse, M., Redfern, J., \& Finch, E. (2019a). The influence of base-salt relief, rift topography and regional events on salt tectonics offshore Morocco. Marine and Petroleum Geology, 103, 87-113.

Pichel, L. M., Finch, E., \& Gawthorpe, R. L. (2019b). The Impact of Pre-Salt Rift Topography on Salt Tectonics: A Discrete-Element Modeling Approach. Tectonics, 38(4), 1466-1488.

Pichel, L. M., Jackson, C. A. L., Peel, F., \& Dooley, T. P. (2019c). Base-salt relief controls salt-tectonic structural style, São Paulo Plateau, Santos Basin, Brazil. Basin Research.

Pichel, L. M., \& Jackson, C. A-L., (2020) Four-dimensional Variability of Composite Halokinetic Sequences. Basin Research.

Quirk, D. G., Schødt, N., Lassen, B., Ings, S. J., Hsu, D., Hirsch, K. K., Von Nicolai, C. (2012). Salt tectonics on passive margins: examples from Santos, Campos and Kwanza basins. Geological Society, London, Special Publications, 363(1), 207-244.

Quirk, D. G., \& Pilcher, R. S. (2012). Flip-flop salt tectonics. Geological Society, London, Special Publications, 363(1), 245-264.

Roberts, A. M., Kusznir, N. J., Yielding, G., \& Styles, P. (1998). 2D flexural backstripping of extensional basins; the need for a sideways glance. Petroleum Geoscience, 4(4), 327-338.

Rodriguez, C. R., Jackson, C. L., Rotevatn, A., Bell, R. E., Francis, M. (2019). Dual tectonic-climatic controls on salt giant deposition in the Santos Basin, offshore Brazil. Geosphere, 14(1), 215-242.

Rowan, M. G., Lawton, T. F., Giles, K. A., \& Ratliff, R. A. (2003). Near-salt deformation in La Popa basin, Mexico, and the northern Gulf of Mexico: A general model for passive diapirism. AAPG bulletin, 87(5), 733-756.

Rowan, M. G., Peel, F. J., \& Vendeville, B. C. (2004). Gravity-driven fold-belts on passive margins.

Rowan, M. G., \& Ratliff, R. A. (2012). Cross-section restoration of salt-related deformation: Best practices and potential pitfalls. Journal of Structural Geology, 41, 24-37. 
782 Rowan, M. G., Giles, K. A., Hearon IV, T. E., Fiduk, J. C. (2016). Megaflaps adjacent 783 to salt diapirs. AAPG Bulletin, 100(11), 1723-1747.

784 Sclater, J. G., \& Christie, P. A. (1980). Continental stretching: An explanation of the 785 post-mid-Cretaceous subsidence of the central North Sea basin. Journal of 786 Geophysical Research: Solid Earth, 85(B7), 3711-3739.

787 Scotchman, I. C., Marais-Gilchrist, G., Souza, F., Chaves, F. F., Atterton, L. A., 788 Roberts, A., \& Kusznir, N. J. (2006). A failed sea-floor spreading centre, Santos Basin, 789 Brasil. In Rio Oil \& Gas Expo and Conference. Rio de Janeiro, Brazil, Brazilian 790 Petroleum, Gas and Biofuels Institute.

791 Scotchman, I. C., Gilchrist, G., Kusznir, N. J., Roberts, A. M., \& Fletcher, R. (2010). 792 The breakup of the South Atlantic Ocean: formation of failed spreading axes and 793 blocks of thinned continental crust in the Santos Basin, Brazil and its consequences 794 for petroleum system development. In Geological Society, London, Petroleum 795 Geology Conference series (Vol. 7, No. 1, pp. 855-866). Geological Society of London. 796 Szatmari, P. M. C. M., Guerra, M. C. M., \& Pequeno, M. A. (1996). Genesis of large 797 counter-regional normal fault by flow of Cretaceous salt in the South Atlantic Santos 798 Basin, Brazil. Geological Society, London, Special Publications, 100(1), 259-264.

799 Vendeville, B. C., Jackson, M. P. A. (1992). The rise of diapirs during thin-skinned 800 extension. Marine and Petroleum Geology, 9(4), 331-354. 
801 FIGURES 

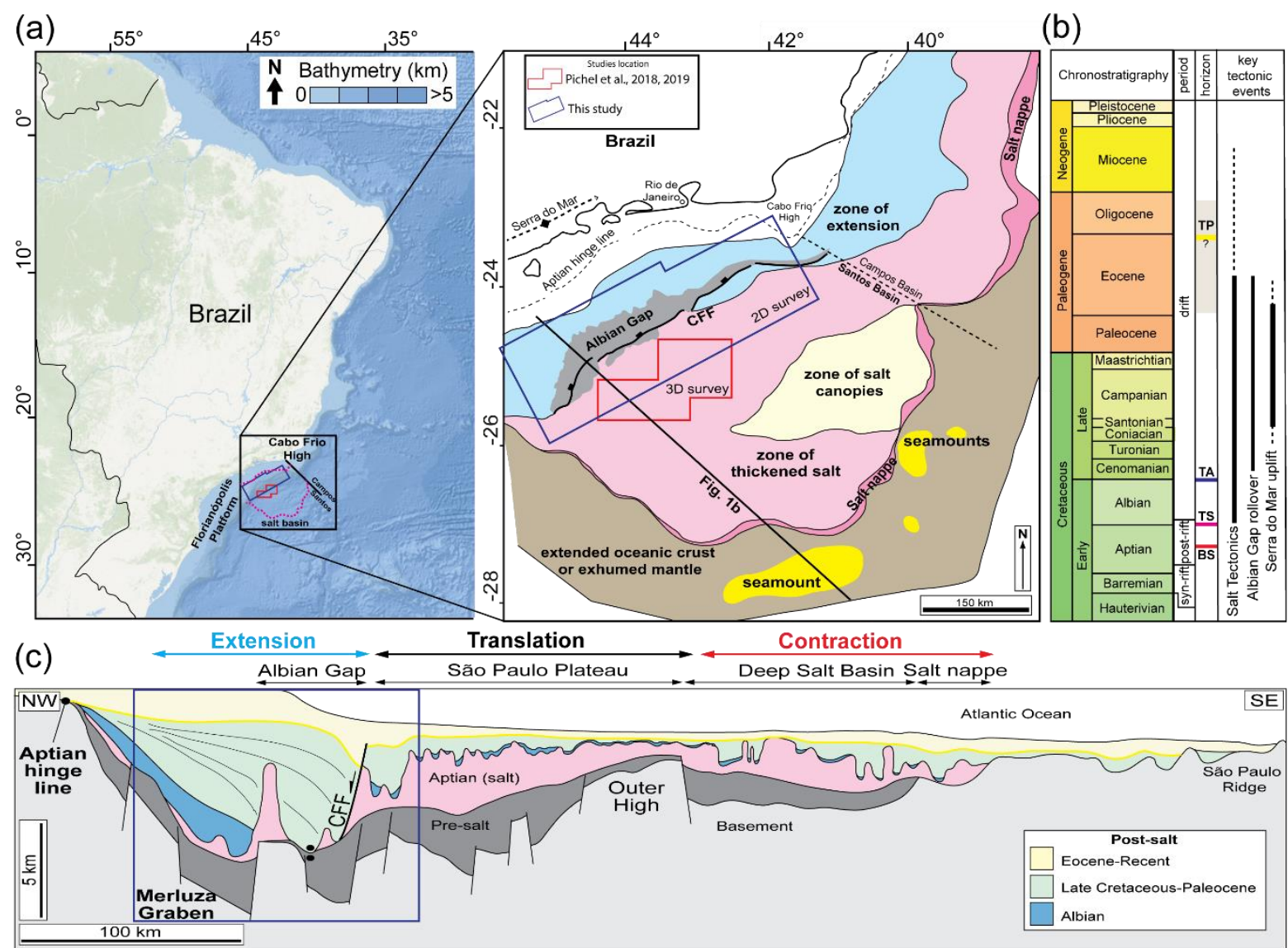

(d)

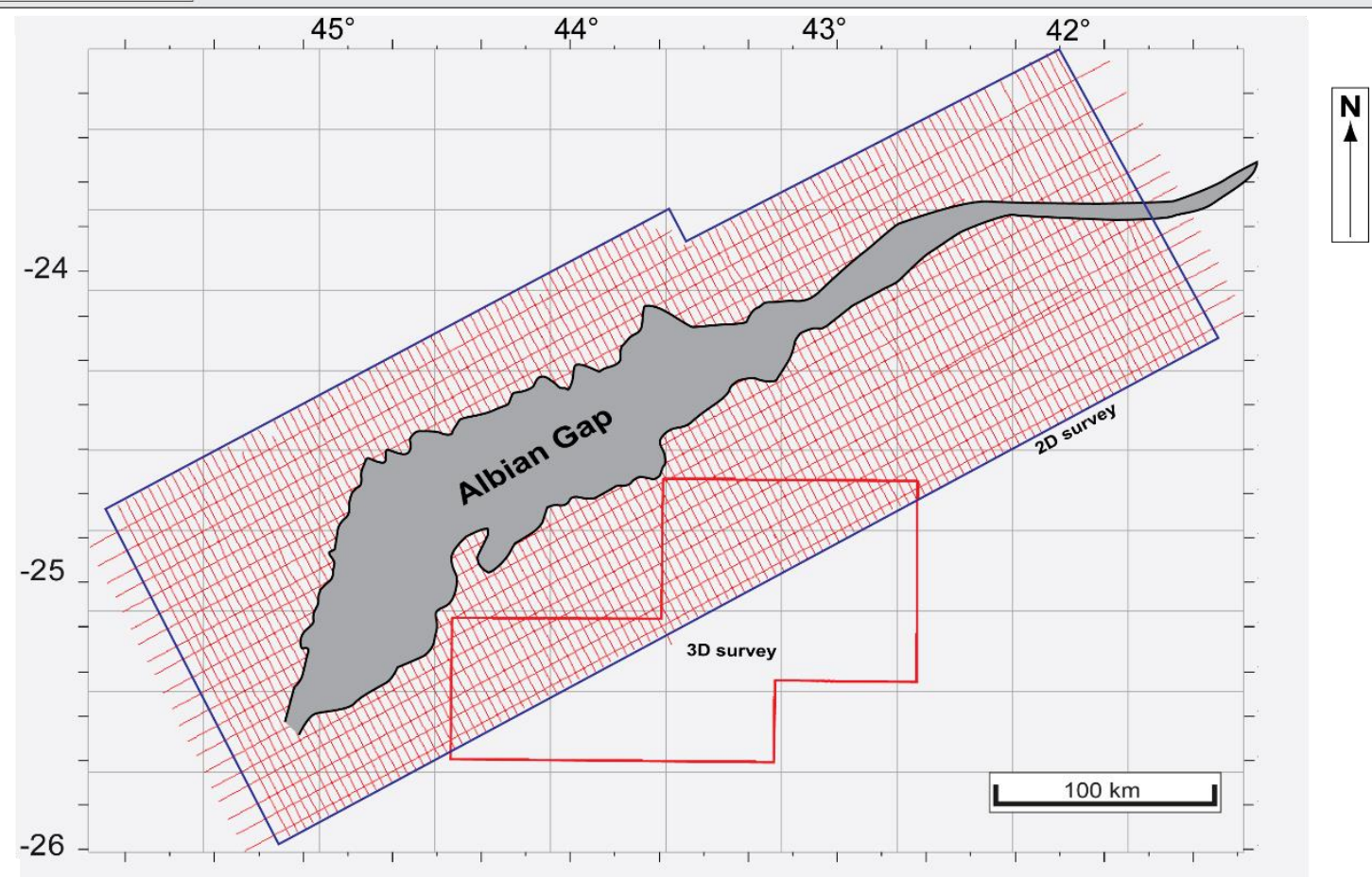

Fig. 1: (a) Bathymetry and structural maps showing the regional salt-related structural domains offshore SE Brazil including a new outline of the Albian Gap. (b) Chrono-stratigraphic chart illustrating the main horizons mapped in this study and timing of relevant tectonic events in the basin (adapted from Davison et al., 2012). (c) Regional geoseismic cross-section showing 
807 the main regional salt-related structural domains offshore the Santos Basin (adapted from 808 Jackson et al., 2015b). Location of the study-area and seismic survey used in the study are 809 shown by a blue polygon in (a) and (c). (d) 2D and 3D seismic survey used in the study and 810 outline of the Albian Gap. In (a) and (b), CFF corresponds to the Albian Gap bounding fault, 811 the Cabo Frio Fault.

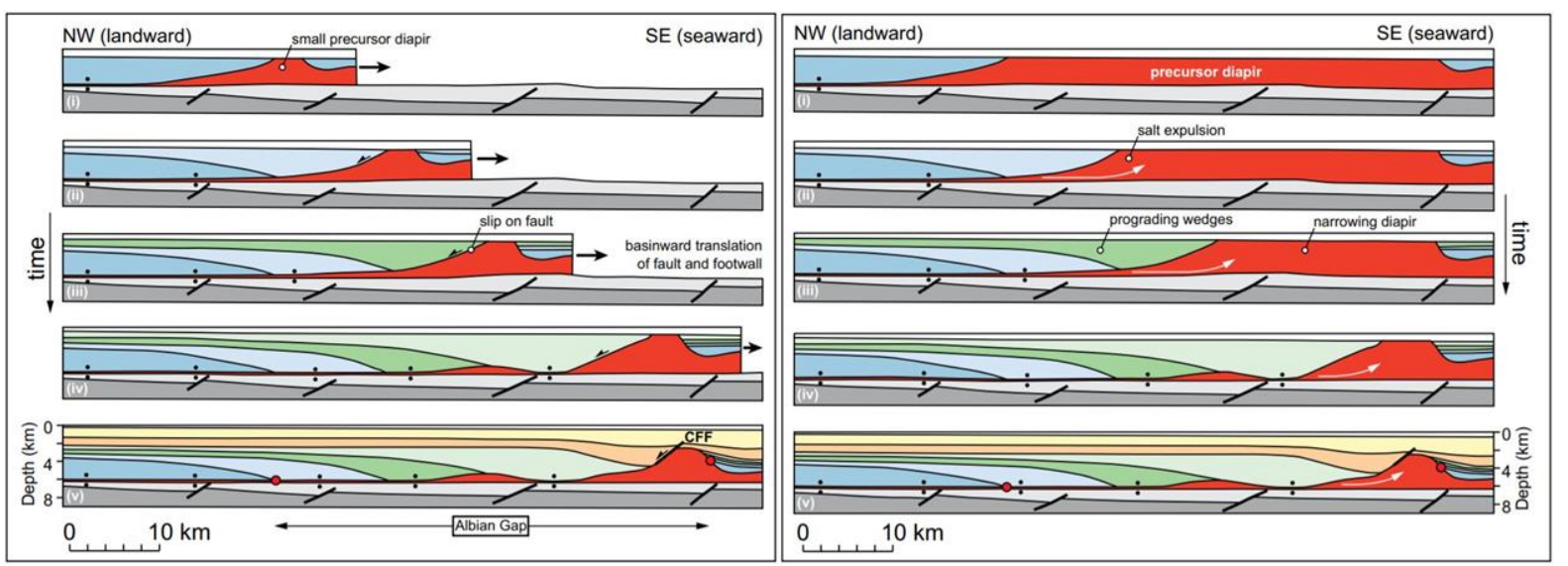

813 Fig. 2: Competing end-member models of the origin and evolution of the Albian Gap: (a) post-

814 Albian extension; (b) post-Albian salt expulsion and basinward inflation (adapted from Rowan and Ratliff, 2012, no vertical exaggeration). Note flat datum during each restoration step. Red dots indicate the limits of the Albian interval and, thus, the extent of the Albian Gap. 


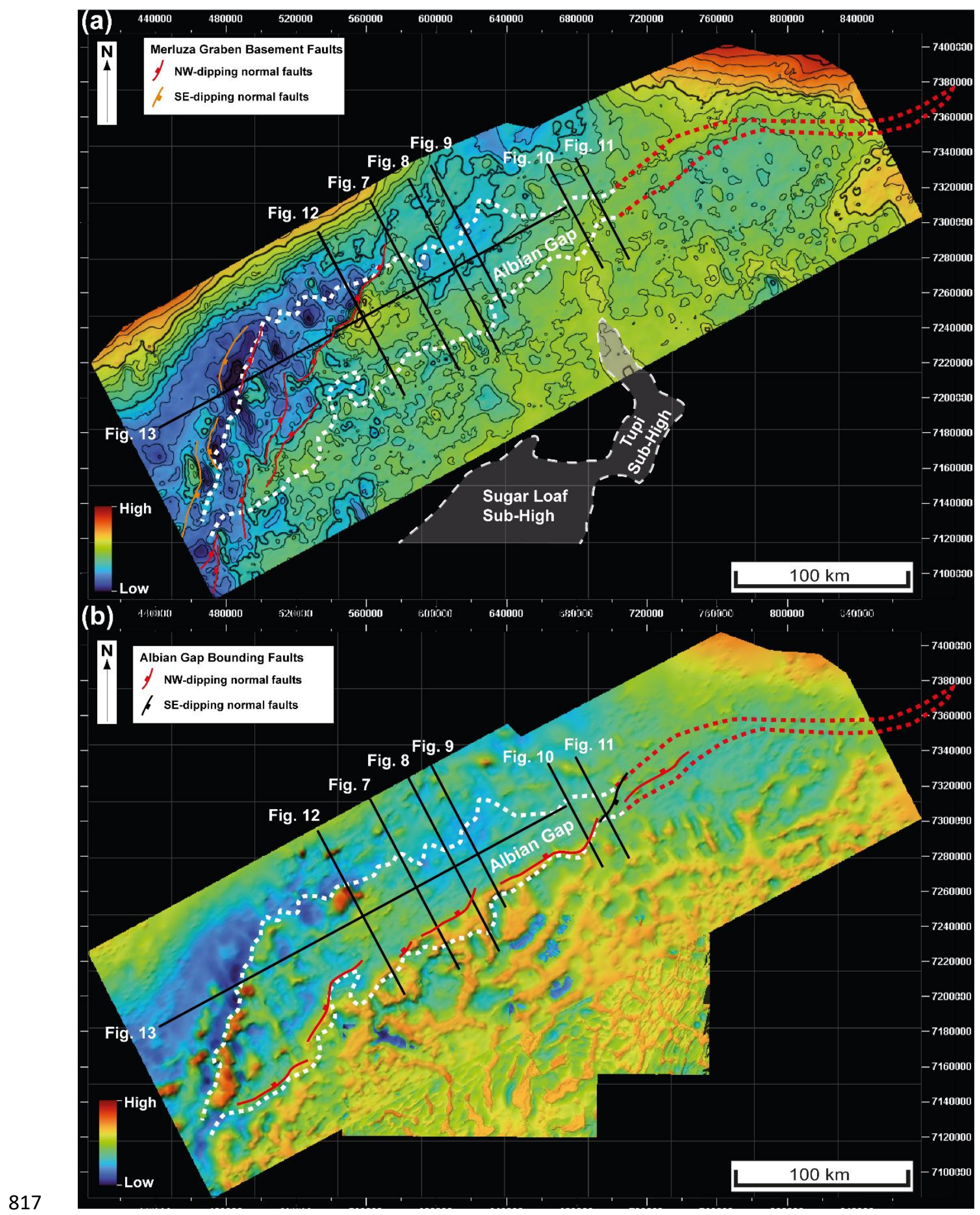

818 Fig. 3: (a) Base-salt map showing the location of main pre-salt rift faults associated with the

819 Merluza Graben and the Tupi and Sugar-Loaf Sub-Highs (cf. Pichel et al., 2019) downdip from 820 the study-area. (b) Top-Salt map showing the distribution of main salt-detached thin-skinned 


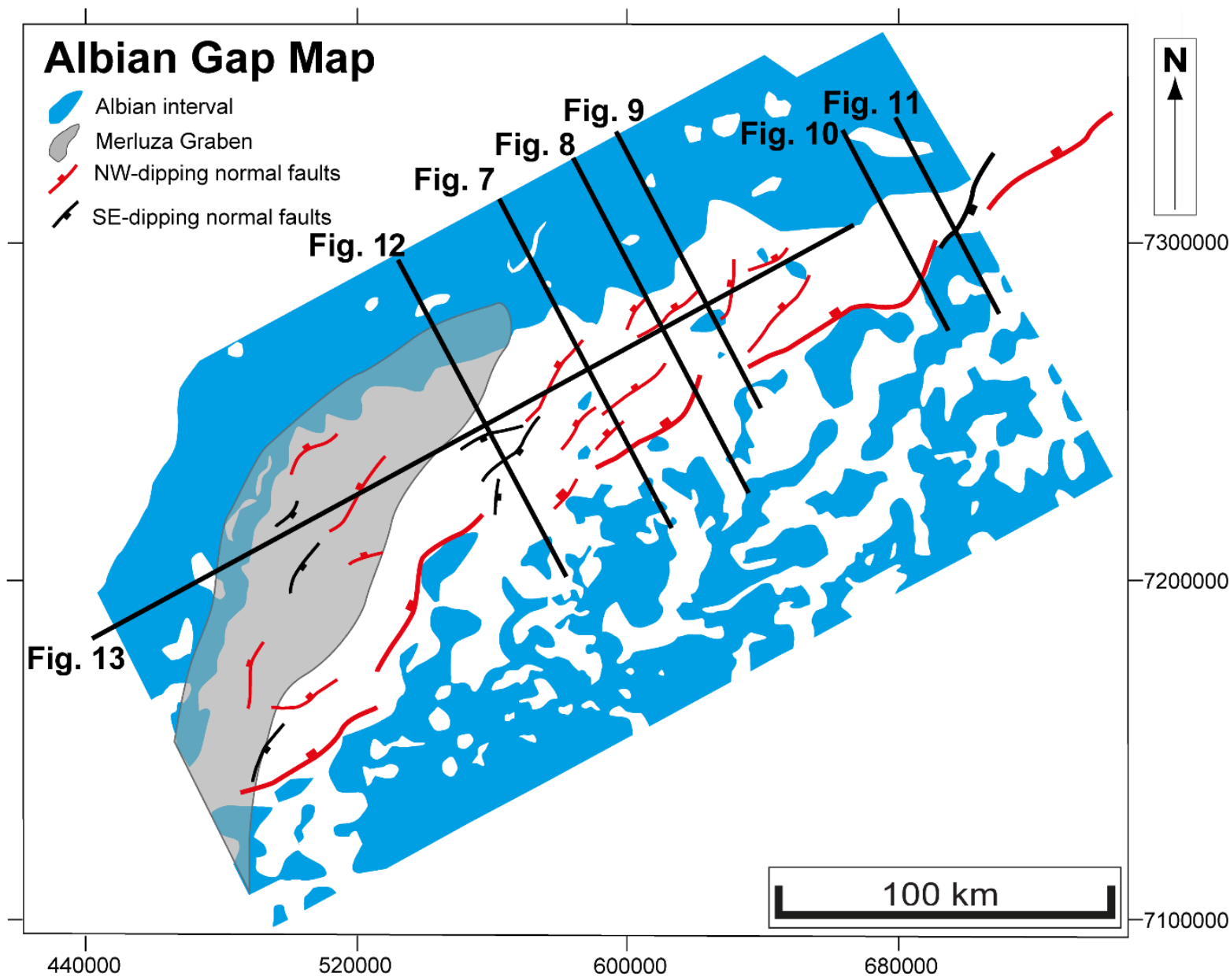

520000

600000

680000

824 Figure 4: Map showing the distribution of the Albian interval and outline of the Albian Gap. The pre-salt Merluza Graben and the main thin-skinned salt-detached normal faults associated with the Albian Gap rollover are also indicated. Note remnants of the Albian interval within the gap in its central-north portion. 
a)

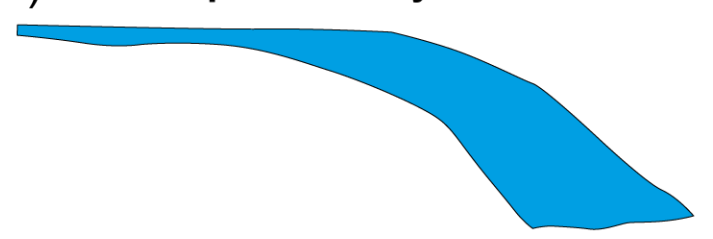

restored (flat datum)

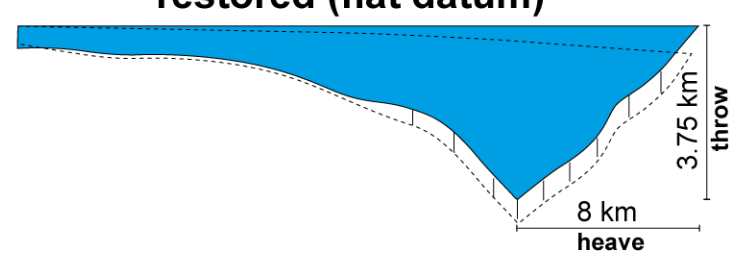

restored (dipping seabed)

VE: 2

c)

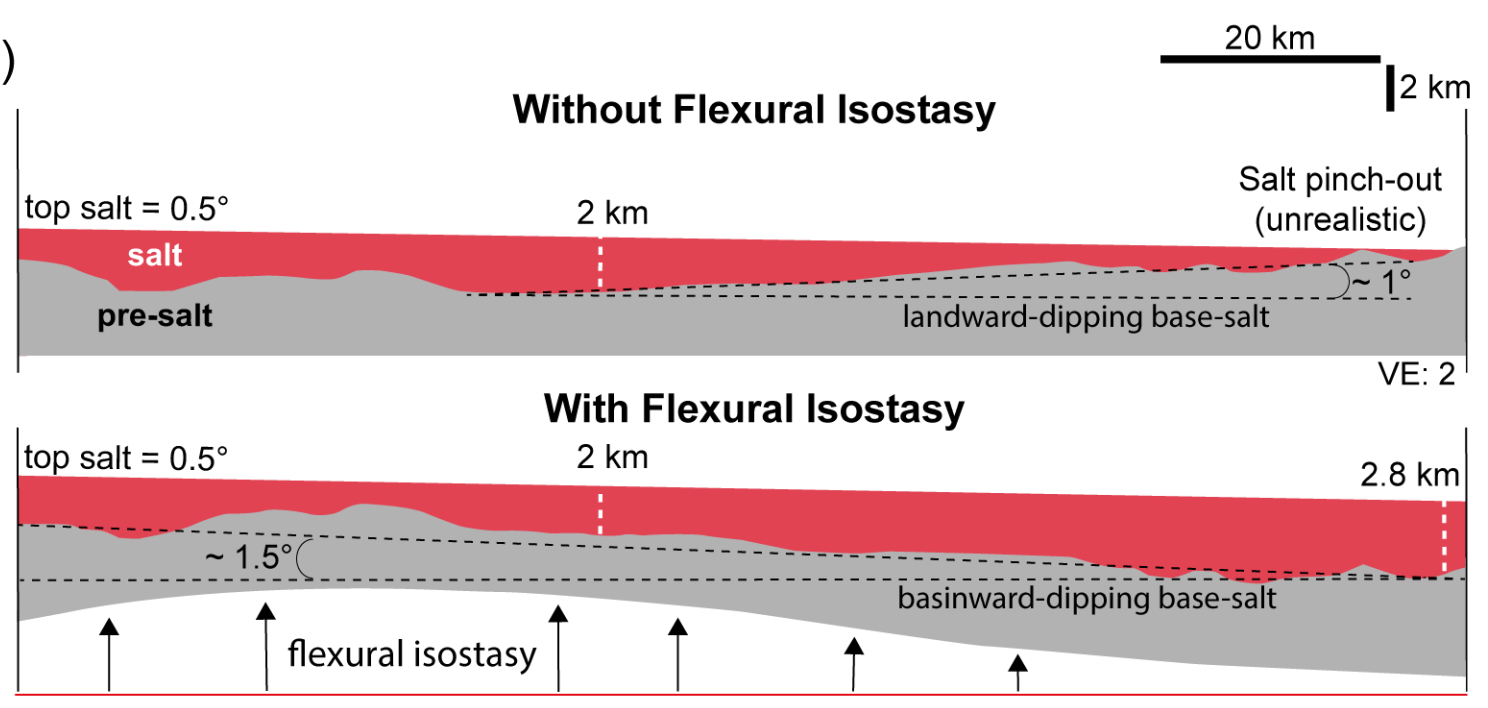

b)

restored (without decompaction)

approx. $25 \%$ of area loss

restored (with decompaction)

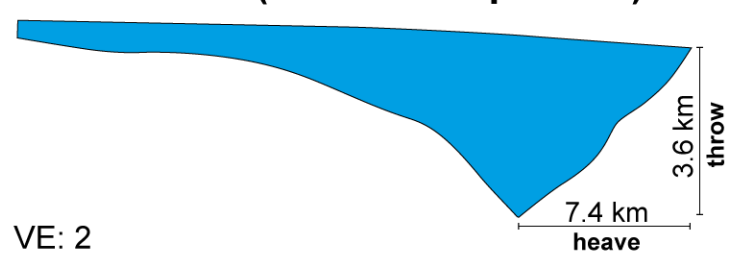

VE: 2

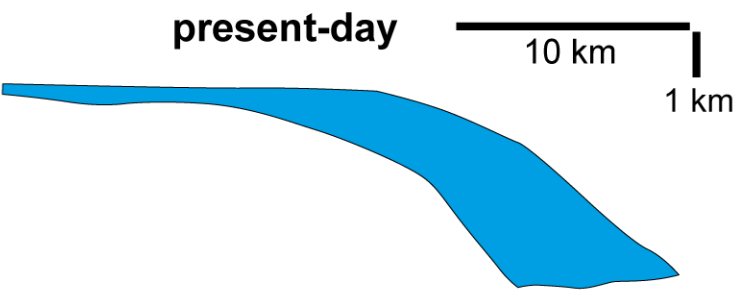

831

Figure 5: Synthetic diagram comparing restoration workflows and illustrating the novel and more geologically realistic approaches utilized in the study. (a) Comparison between rollover wedges being restored to a flat-datum (previous studies, see fig. 2) and to a gently-dipping seabed (this study). The former overestimates extension as the throw and heave are larger than when restoring these sequences to a gently-dipping slope bathymetry. (b) Same wedge from (a) is restored with and without decompaction for comparison. There is c. $25 \%$ of loss in area/volume, and thus overall thickness as well as less throw (c $1.1 \mathrm{~km}$ ) when decompaction is not incorporated in the workflow. (c) Comparison between restorations without (previous studies) and with flexural isostasy (this study), in which the isostatic effects caused by 
an anomalous landward dip throughout the entire workflow, which results also in unrealistic 843 distal salt thicknesses. In the latter, the base-salt gradually changes through time and switches back to a more realistic initial basinward dip resulting also in more reasonable salt thickness

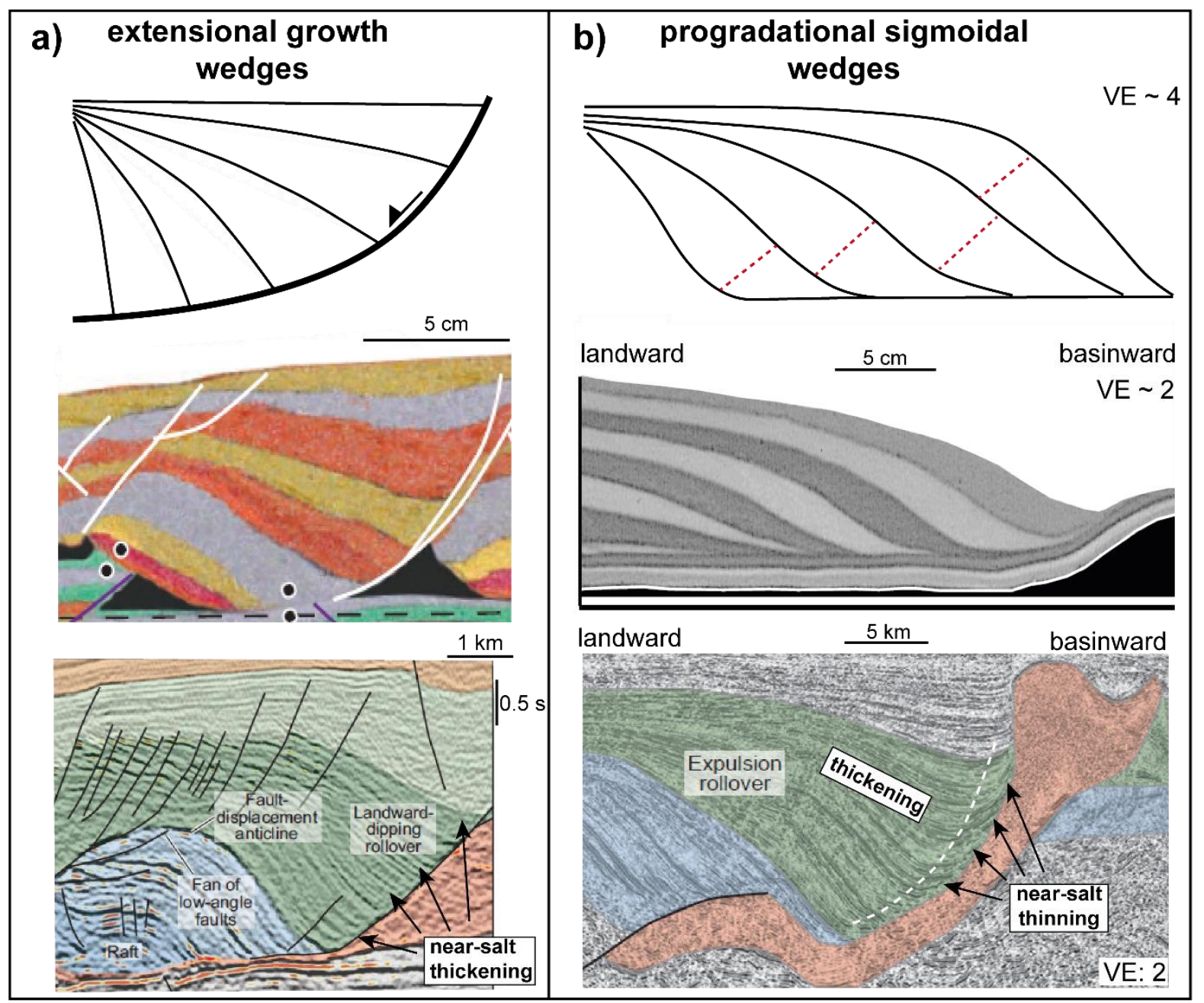

Figure 6: Different styles of rollover growth wedges: a) basinward-thickening extensional wedges with a physical model example in the second row (adapted from Jackson and Hudec, 2017) and a seismic example from the Kwanza Basin, Angola in the third-row (after Chimney and Kluth, 2002 and Jackson and Hudec, 2017), and b) basinward-thinning clinoform sigmoidal growth wedges with a physical model example in the second row (adapted from Ge et al., 1997) and a seismic example from the Gulf of Mexico (adapted from Jackson and Hudec, 2017). 


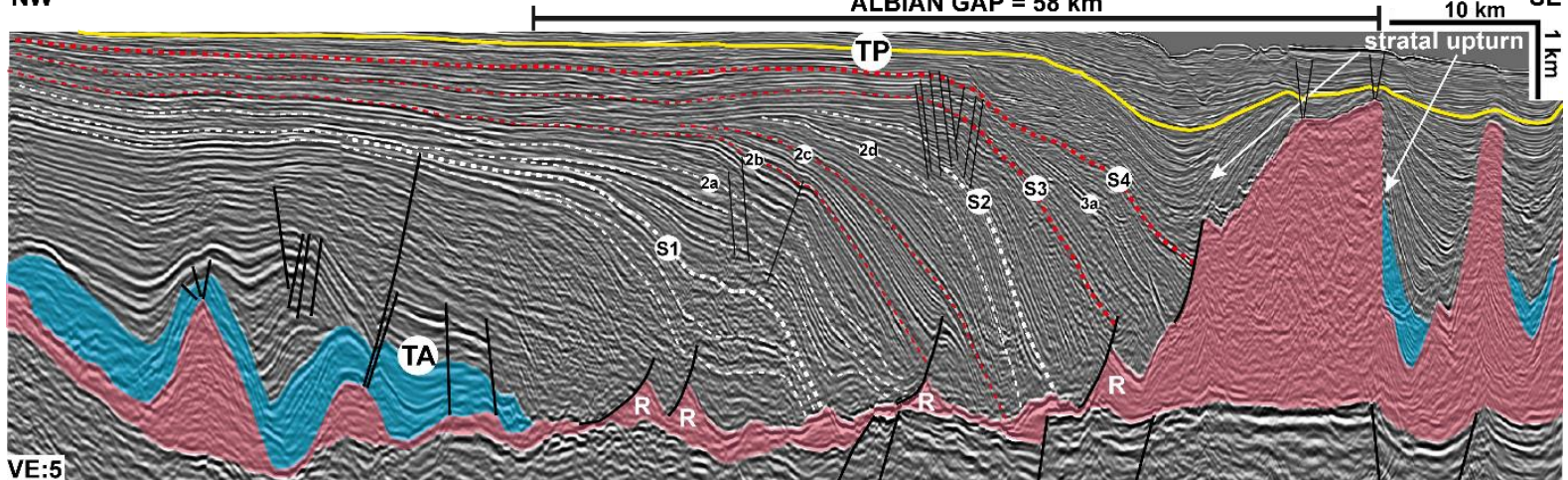

857 Figure 7: South-central dip-oriented section from the Albian Gap. Salt in pink, Albian in blue, normal faults in black and an intra-Paleogene regional unconformity in yellow. The main postAlbian rollover sequences are indicated by thick dashed lines and named S1-S4, intermediate intervals are numbered and indicated by thin dashed lines for correlation purposes. The postAlbian rollover presents contrasting growth wedges: expulsion-dominated basinward-thinning, sigmoidal wedges (white) and extension-dominated basinward-thickening wedges (red). The gap is $58 \mathrm{~km}$ wide being composed by a $50 \mathrm{~km}$ wide basinward-dipping rollover and an $8 \mathrm{~km}$ wide salt wall with strata upturn on both its flanks. The gap is also associated with small landward-dipping listric normal faults that become progressively younger basinward. Small salt rollers indicated by (R). Seismic data courtesy of TGS and WesternGeco.

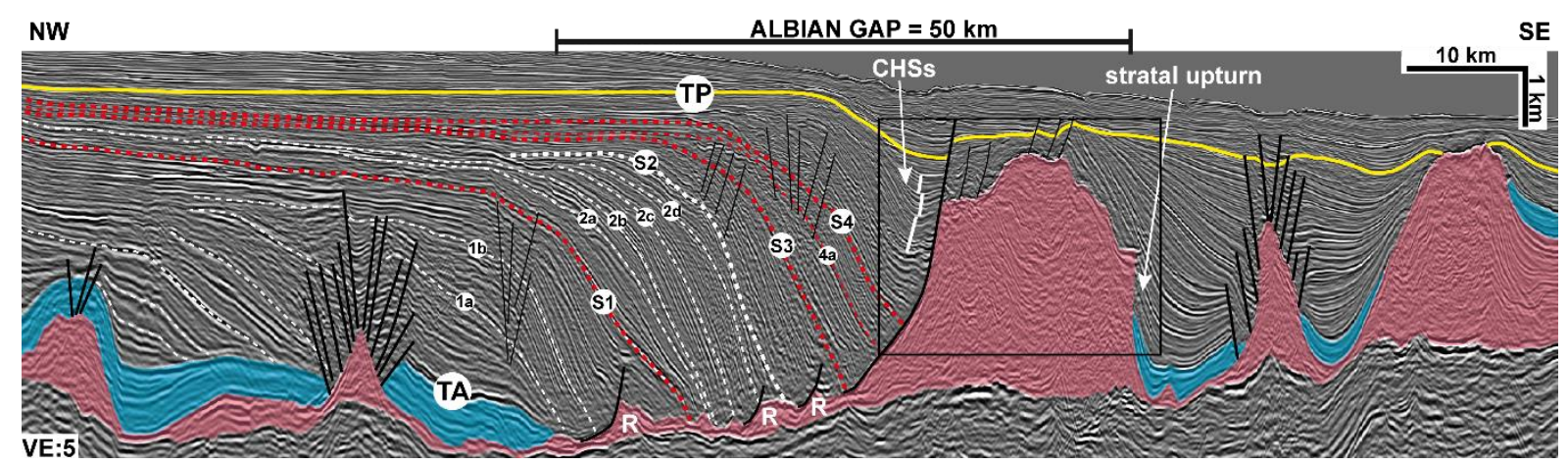

Figure 8: Central dip-oriented section from the Albian Gap. Salt in pink, Albian in blue, normal faults in black and an intra-Paleogene regional unconformity in yellow. The main post-Albian rollover sequences are indicated by thick dashed lines and named S1-S4, intermediate 871 intervals are numbered and indicated by thin dashed lines for correlation purposes. The post-

872 Albian rollover presents contrasting growth wedges: expulsion-dominated sigmoidal wedges 873 (white) and extension-dominated basinward-thickening wedges (red). The gap is $50 \mathrm{~km}$ wide 874 being composed of a $40 \mathrm{~km}$ wide basinward-dipping rollover and a $10 \mathrm{~km}$ wide salt wall with strata upturn and halokinetic sequences (thick white lines) on its flanks and a large landwarddipping normal fault on its landward side. The gap is also associated with small landwarddipping listric normal faults that become progressively younger basinward. Small salt rollers 


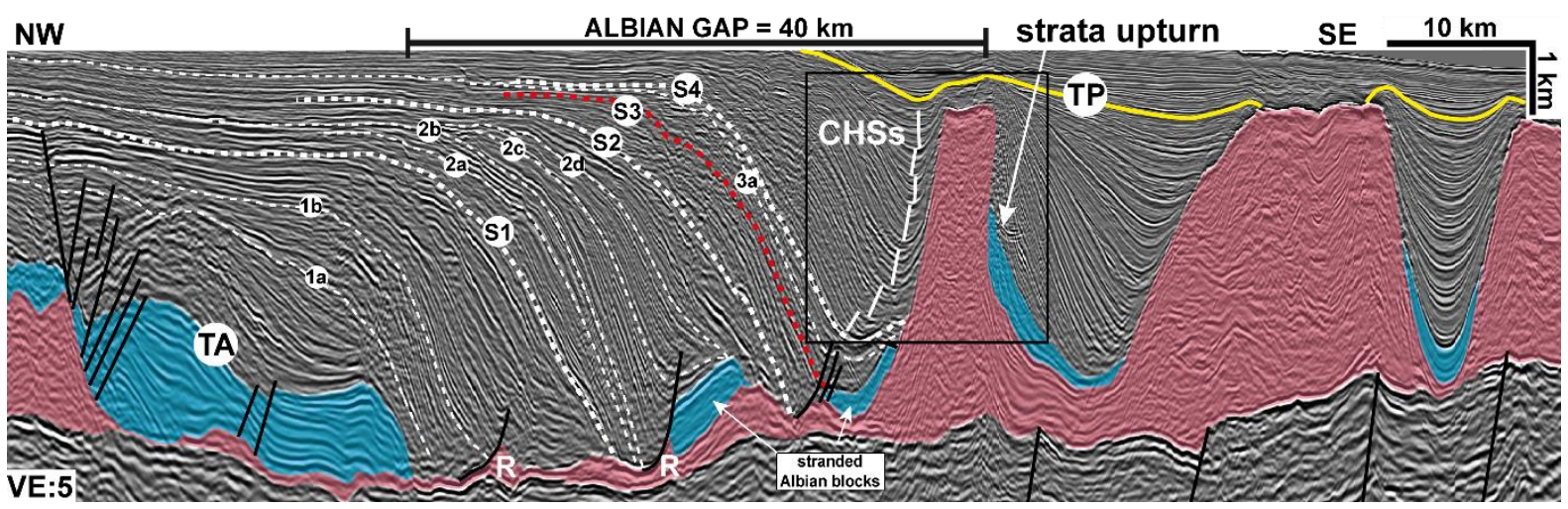

Figure 9: North-central dip-oriented section from the Albian Gap. Salt in pink, Albian in blue, normal faults in black and an intra-Paleogene regional unconformity in yellow. The main postAlbian rollover sequences are indicated by thick dashed lines and named S1-S4, intermediate intervals are numbered and indicated by thin dashed lines for correlation purposes. The postAlbian rollover presents contrasting growth wedges: expulsion-dominated sigmoidal wedges (white) and extension-dominated basinward-thickening wedges (red). The gap is $40 \mathrm{~km}$ wide upturn and halokinetic sequences (thick white lines) on its flanks. The gap is also associated and occasionally downlap remnant Albian blocks. Small salt rollers indicated by $(R)$. Seismic data courtesy of TGS and WesternGeco. Black square represents the zoomed-in section of figure 15.

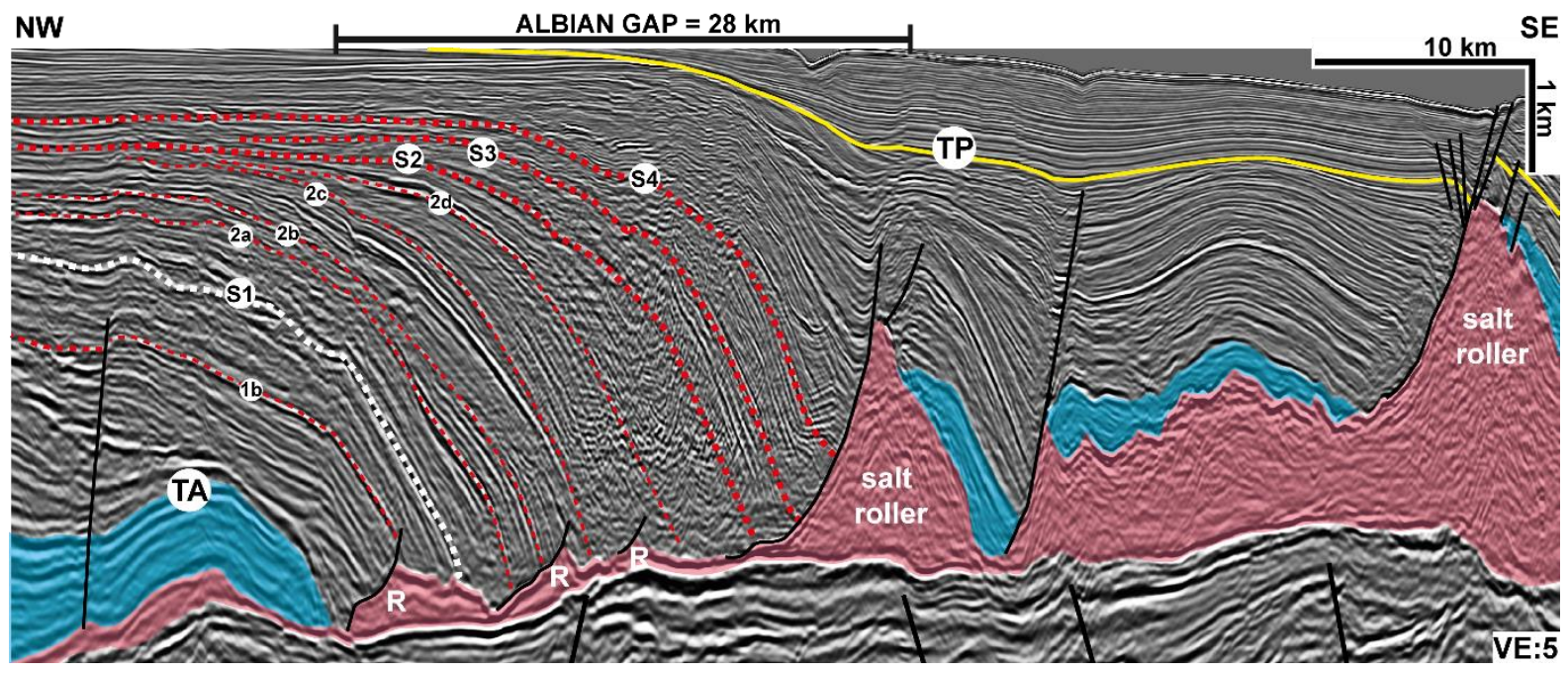


rollover sequences are indicated by thick dashed lines and named S1-S4, intermediate intervals are numbered and indicated by thin dashed lines for correlation purposes. The gap is $28 \mathrm{~km}$ wide being composed of a $27 \mathrm{~km}$ wide basinward-dipping rollover and c.1 km wide reactive (extensional) salt wall/roller defined by a large landward-dipping normal fault. The post-Albian rollover is dominated by basinward-thickening, extensional wedges (red dashed lines) associated with small landward-dipping listric normal faults that become progressively younger basinward. Only one expulsion-dominated sigmoidal wedge is observed (white dashed line) in the lower sequences. Small salt rollers indicated by $(R)$. Seismic data courtesy of TGS and WesternGeco.

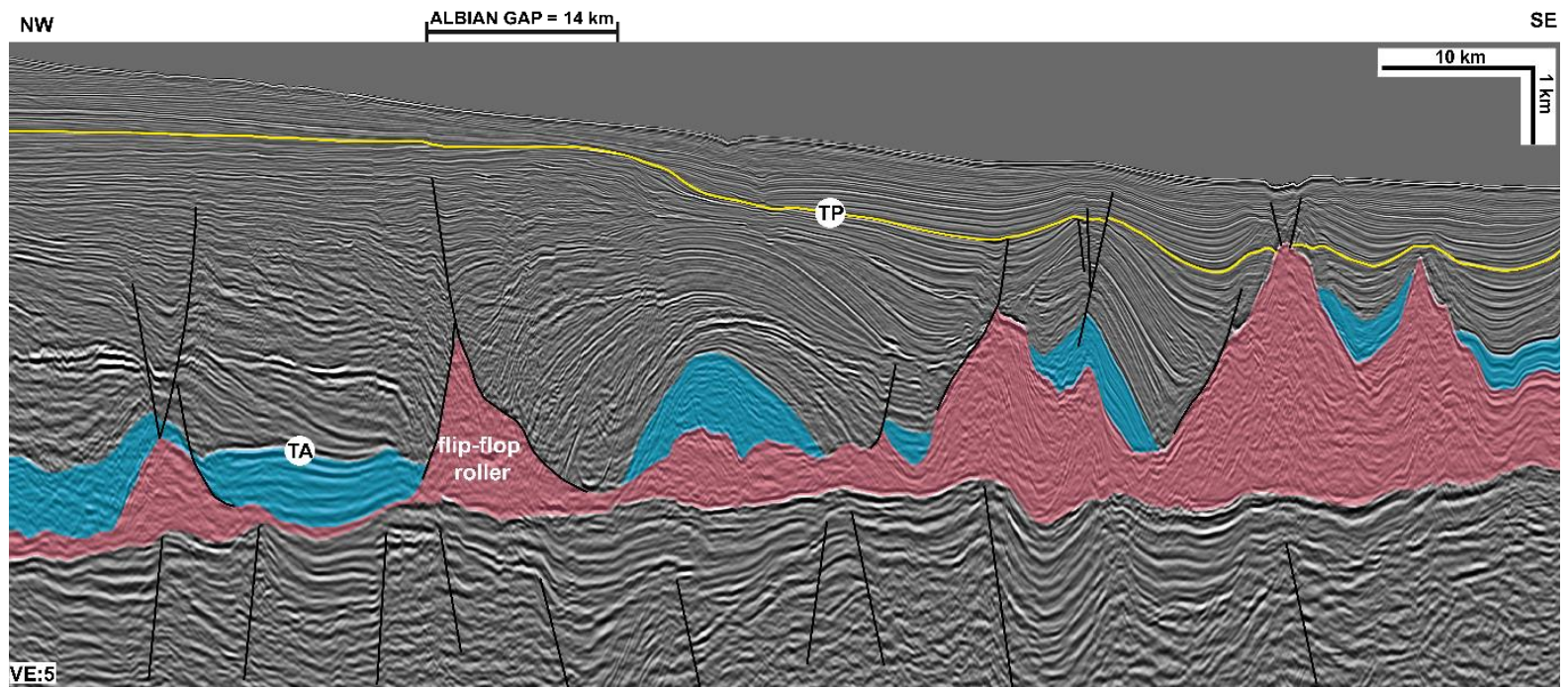

Figure 11: Northernmost section illustrating the switch in fault polarity associated with a flip-

907 Figure 11: Northernmost section illustrating the switch in fault polarity associated with a flip-

908 flop salt reactive diapir bounding the Albian Gap. The gap is significantly narrower (14 km)

909 and associated with a wide $35 \mathrm{~km}$ wide extensional turtle anticline further downdip. Seismic

910 data courtesy of TGS and WesternGeco.

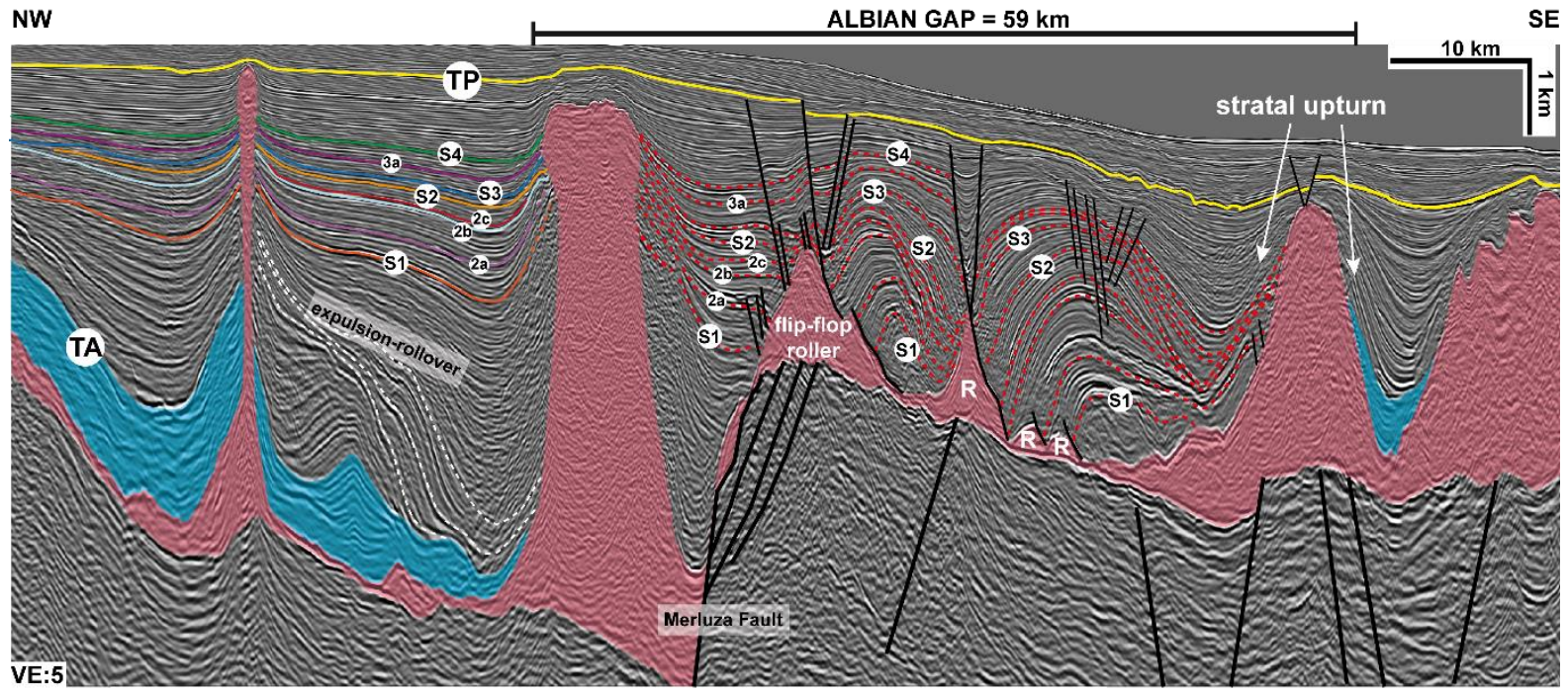

912 Figure 12: Central dip-oriented section from the Albian Gap. Salt in pink, Albian in blue and 
913 normal faults in black. An intra-Paleogene regional unconformity in yellow. The main post-

914 Albian rollover sequences are indicated by thick dashed lines and named S1-S4, intermediate

915 intervals are numbered and indicated by thin dashed lines for correlation purposes. The gap

916 is $58 \mathrm{~km}$ wide. It comprises the downdip edge of the Merluza Graben and a $8 \mathrm{~km}, 8.5 \mathrm{~km}$ tall

917 salt stock at its hangingwall. Further downdip the Albian Gap is defined by two large salt rollers,

918 the updip one with a flip-flop geometry. Basinward-dipping listric normal faults and extensional 919 wedges dominate the post-Albian rollover sequence. In this case, extensional wedges are 920 dominantly landward-thickening (red dashed lines). Expulsion-driven sigmoidal wedges (white 921 dashed lines) occur only updip of the Albian Gap, within the Merluza Graben. Downdip, the 922 Albian Gap is bounded by a diapir that shows significant strata upturn on both flanks.. Small 923 salt rollers indicated by $(R)$. Seismic data courtesy of TGS and WesternGeco.

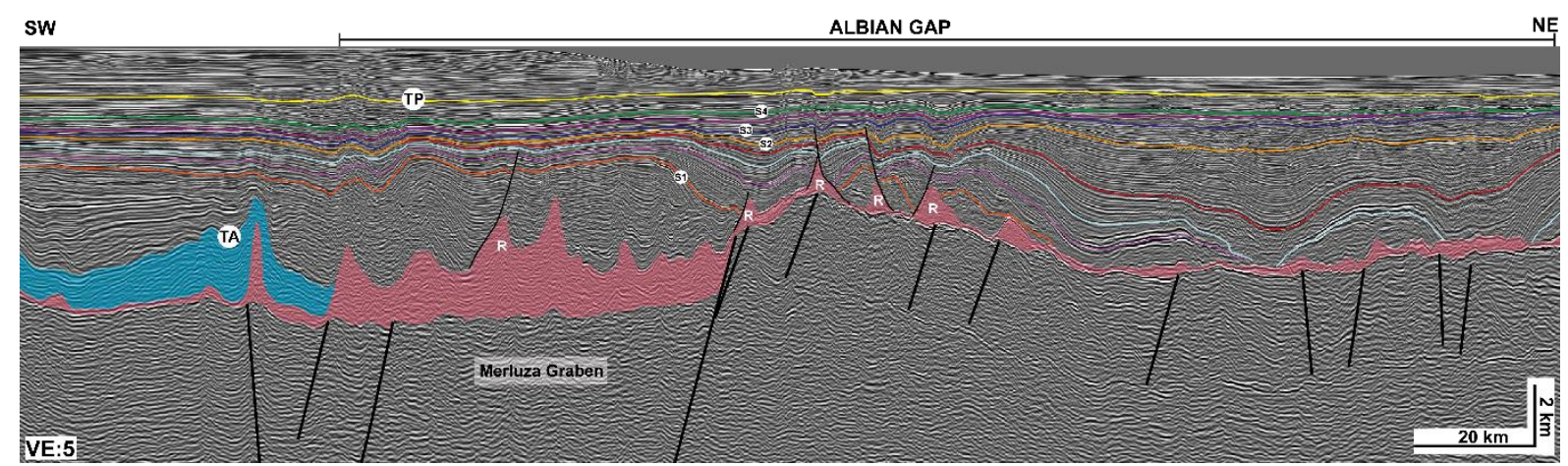

925 Figure 13: Strike-section illustrating the thickness variations with the Albian Gap and its relationship with the Merluza Graben to the south. Salt in pink, Albian in blue, normal faults in black and an intra-Paleogene regional unconformity in yellow. Salt rollers are indicated by $(R)$.

928 The overburden is $9-10 \mathrm{~km}$ to the south, with the post-Albian rollover being up to $9 \mathrm{~km}$ thick; 929 whereas to the north it is on average 6-7 km thick. The main post-Albian rollover sequences 930 are indicated by S1-S4 and with different colours as they vary alongs-strike between 931 expulsion- and extension-dominated in this section. Seismic data courtesy of TGS and 932 WesternGeco. 


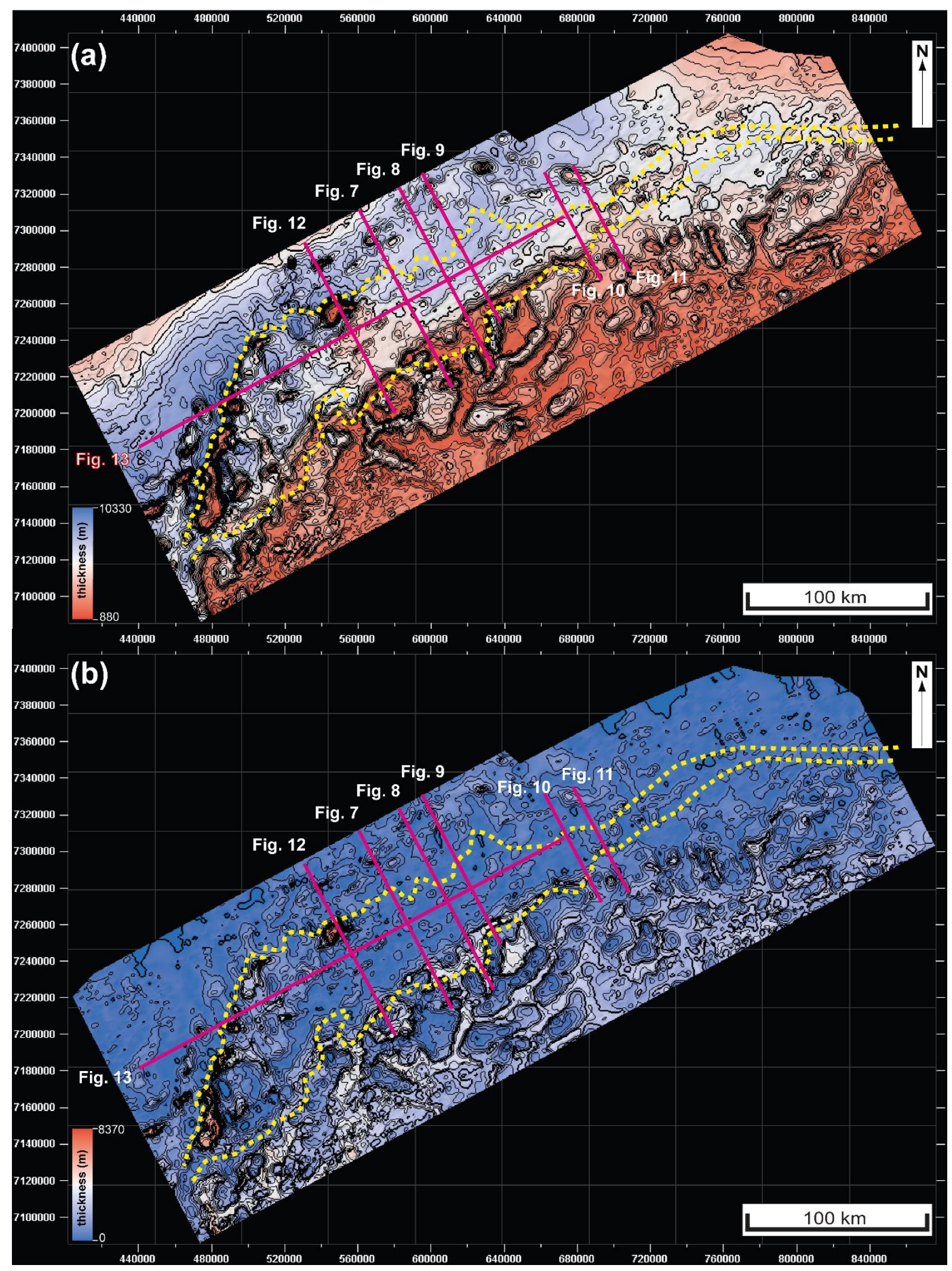

934 Figure 14: (a) Overburden thickness map and (b) salt thickness map. The maximum 935 overburden thickness $(9-10 \mathrm{~km})$ and thinner $(>200 \mathrm{~m})$ salt occur in the proximal domain within 936 the Albian Gap. Albian Gap outline in yellow dashed line. Seismic profiles from figures 7-13 are numbered and shown by pink lines. 


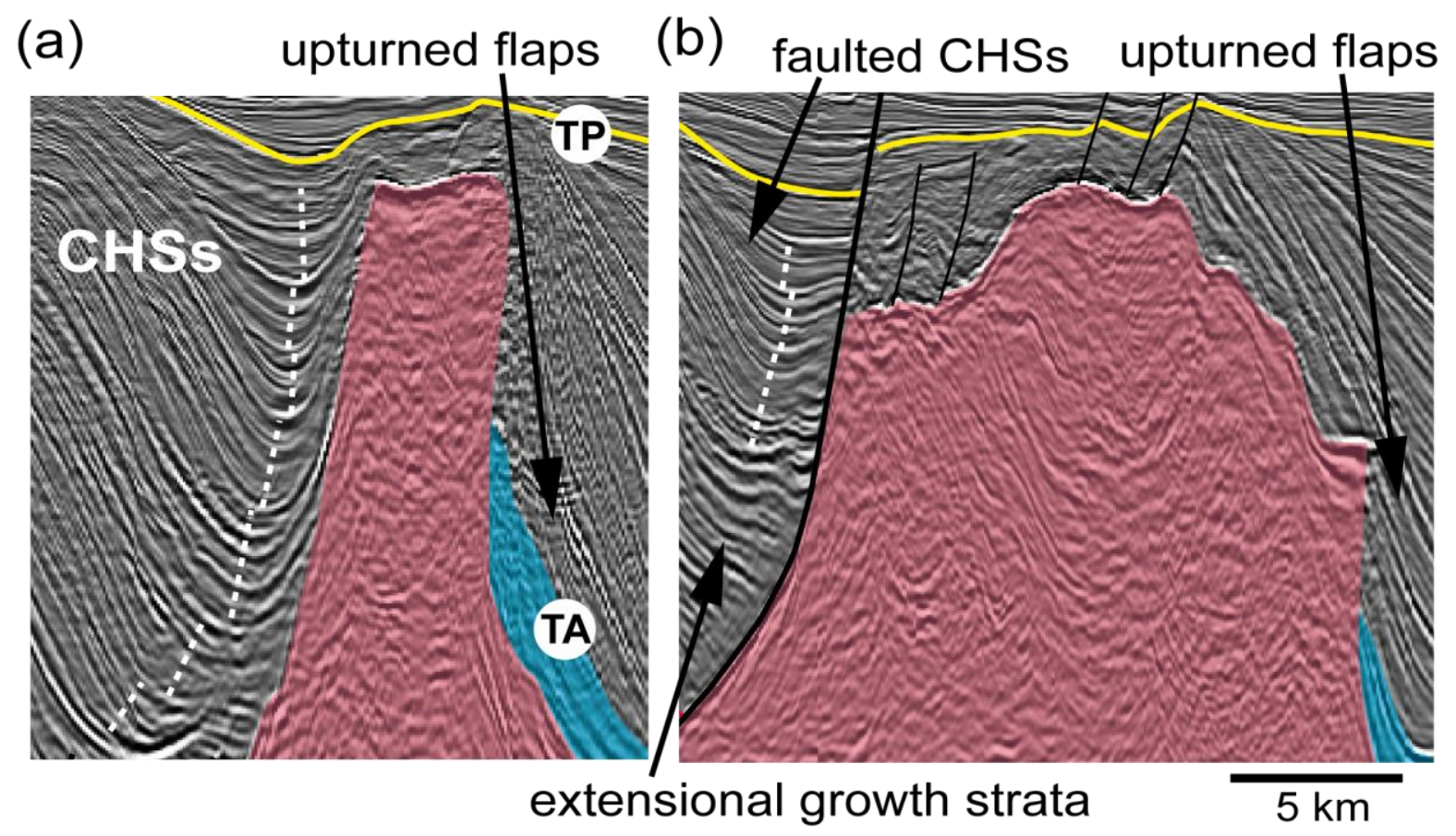

Figure 15: Zoom of near-diapir upturned strata at the downdip edge of the Albian Gap. In (a),

940 zoom from figure 8 showing composite halokinetic sequences (CHSs) characterized by

941 localized (c. $1 \mathrm{~km}$ ) of upturning and thinning on the landward flank of the diapir and larger

942 upturned flaps on its basinward flank. In (b), a significantly wider diapir presents similar

943 upturned flaps on its basinward flank. Its landward flank has a lower extensional rollover with

944 thickening towards the diapir and its bounding fault, whereas the upper section presents

945 characteristic upturn and stratal thinning of CHSs, being later offset due to propagation of the 946 lower normal fault. 

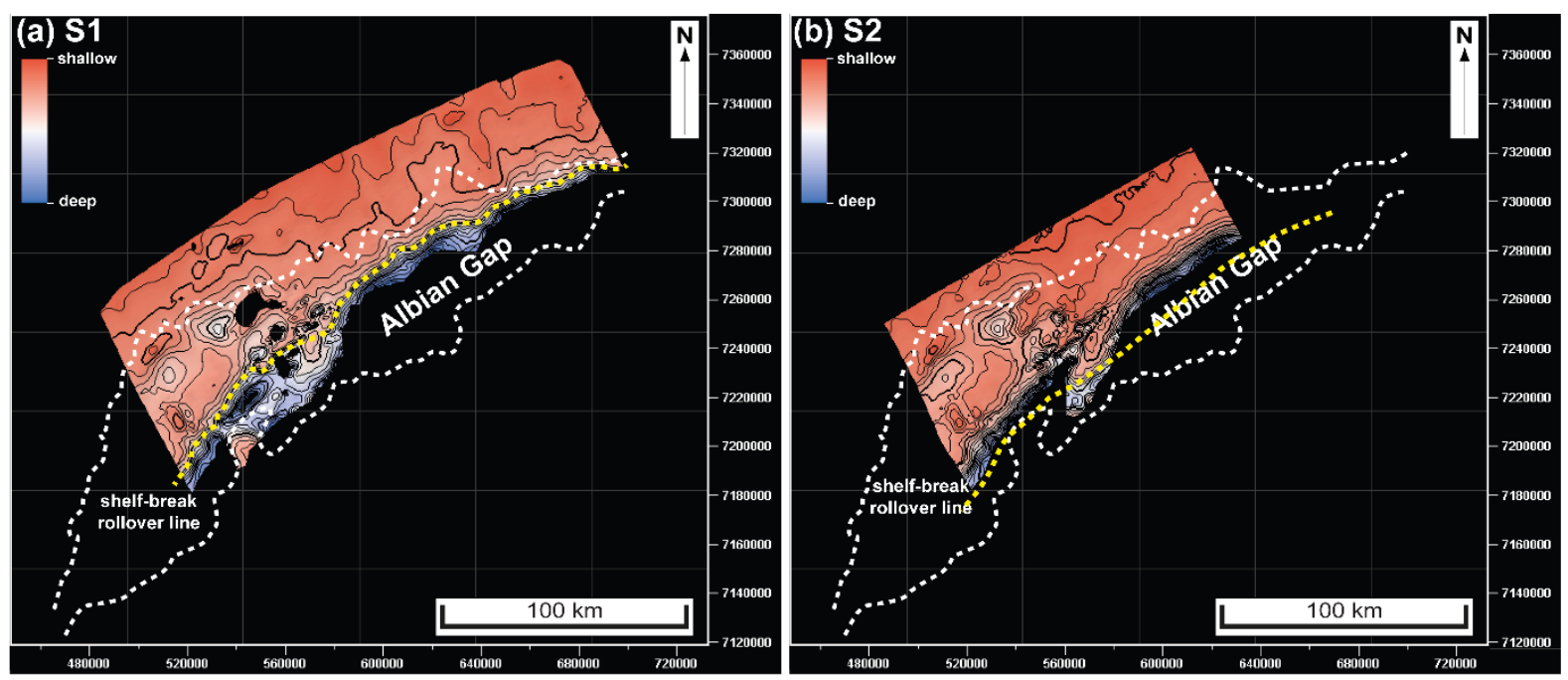

949
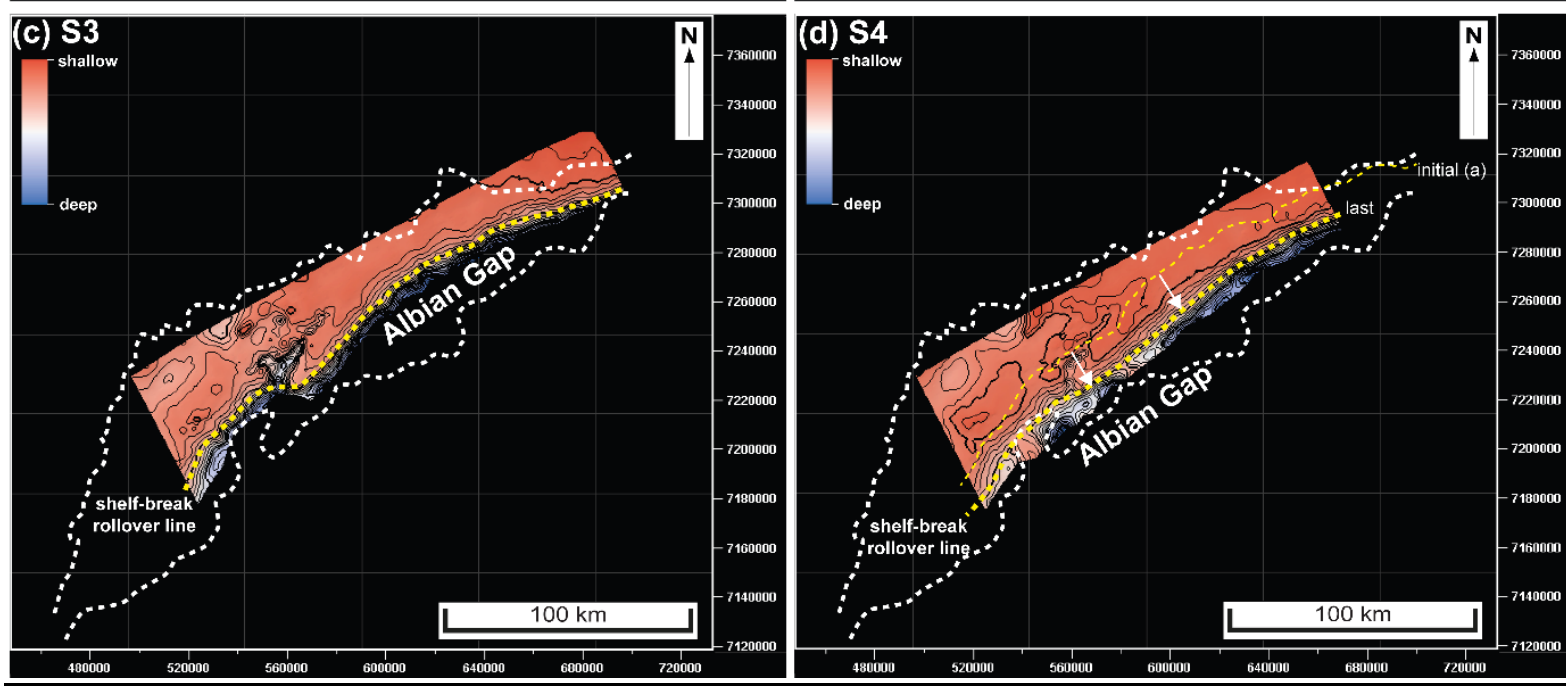

950 Figure 16: Structural maps of key stratigraphic intervals within the post-Albian rollover in the

951 Albian Gap: (a) S1, (b) S2, (c) $S 3$ and (d) $S 4$ from cross-sections (figs. 7-13). The maps

952 demonstrate that in the central-south portion where the Albian gap is wider, the shelf-break 953 rollover point was located $14-20 \mathrm{~km}$ further basinward, indicating greater progradation of 954 sediments. White arrows indicate c. $20 \mathrm{~km}$ of shelf-break advance from the initial stages (top 955 S1) (a) to final stages (top-S4) (d) of margin progradation. 


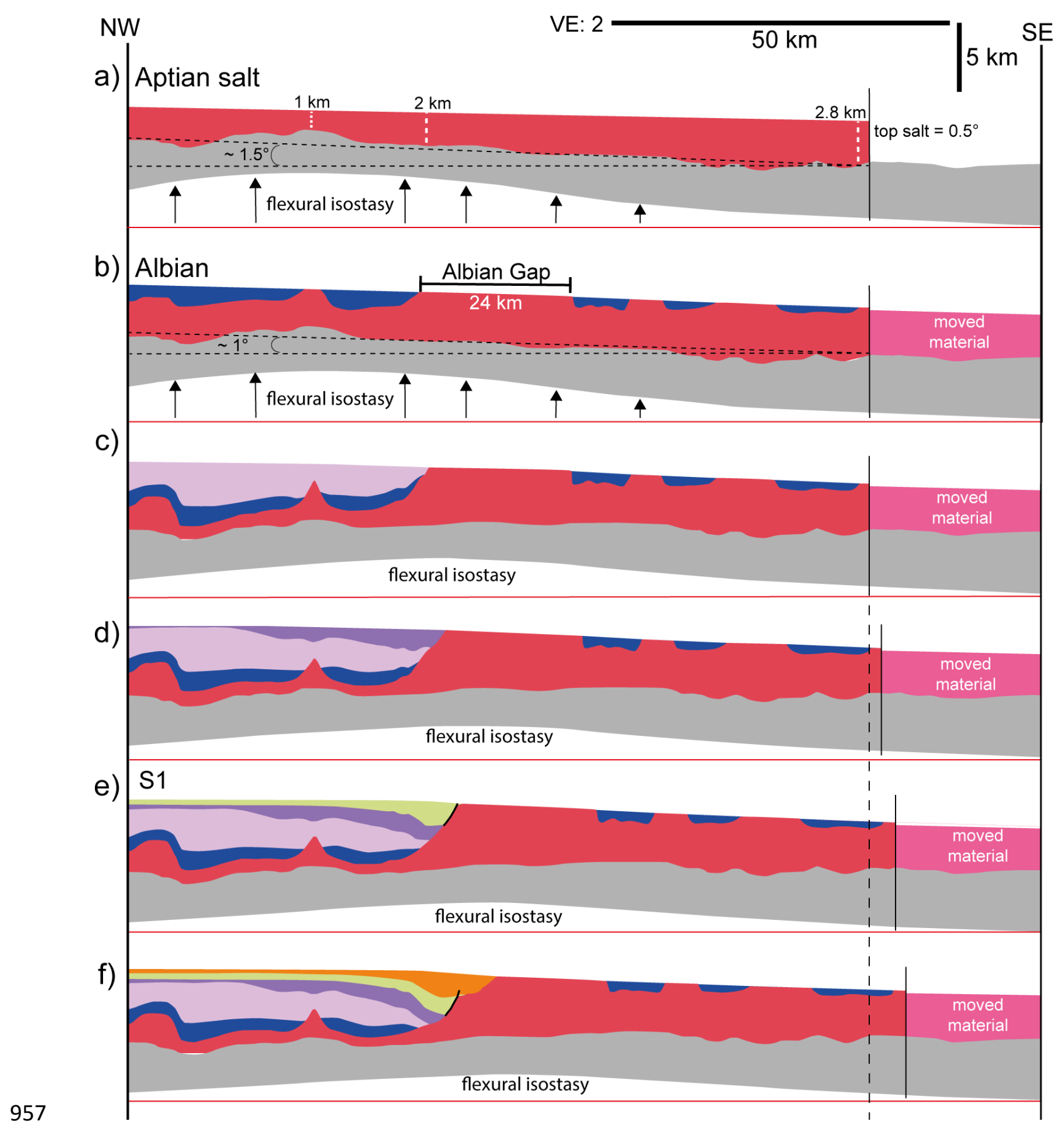




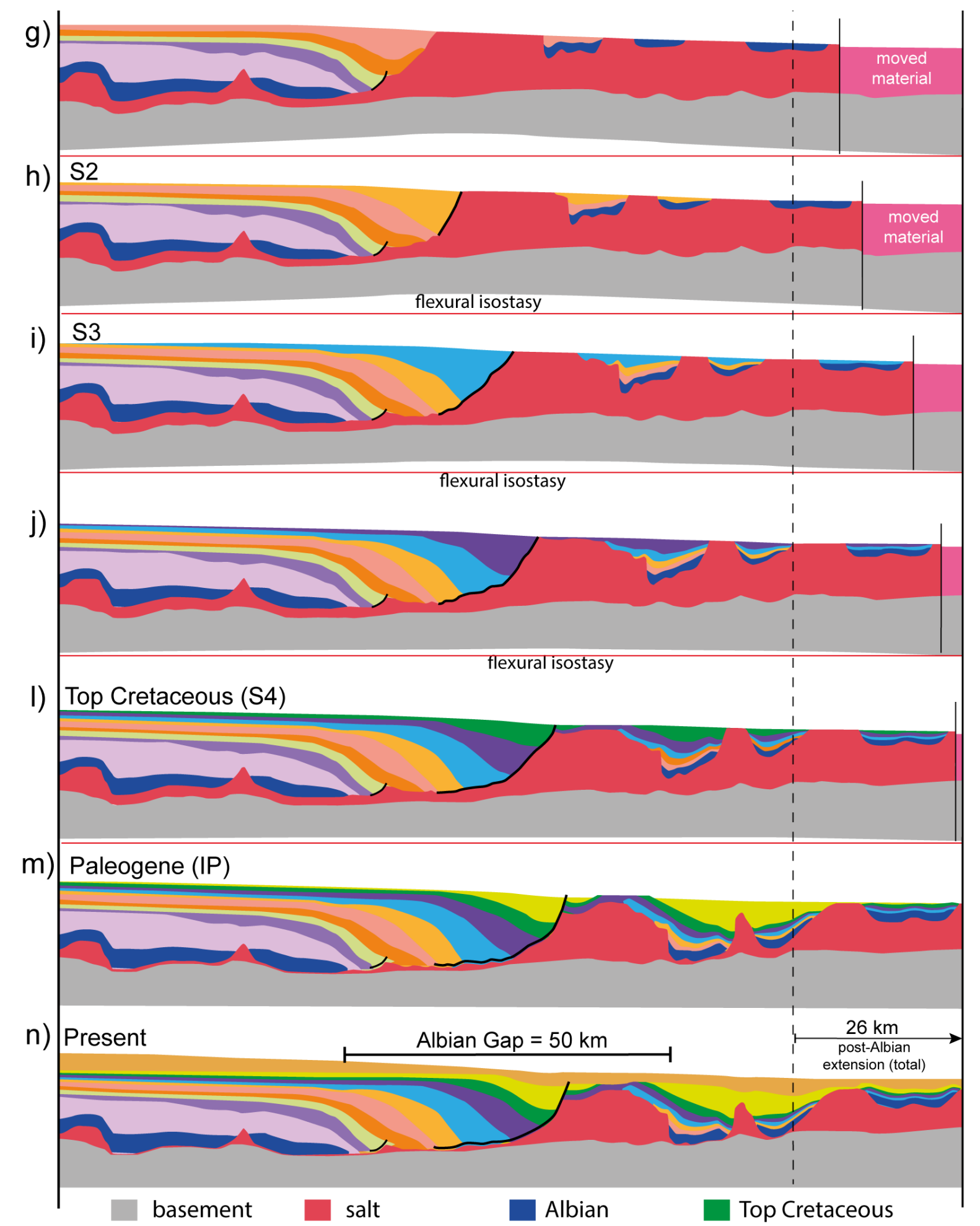

Figure 17: Detailed sequential restoration of the central and most representative section from 960 the Albian Gap. The workflow involves decompaction, unfolding, move on fault and flexural 961 isostasy. Extension on each time-step is indicated by movement of the downdip end wall.

962 Decompaction and unfolding of post-Albian sequences (a-n) demonstrates that the Albian Gap 963 accommodated $26 \mathrm{~km}$ of post-Albian extension and that the gap was initially and partially 964 formed already during the Albian as a $24 \mathrm{~km}$ wide passive salt wall, resulting in a $50 \mathrm{~km}$ wide 
Albian Gap at present. The restoration of the lowermost post-Albian sequences show little (c. $9661 \mathrm{~km}, g-h, h-i, j-l)$ to no (l-m) extension, with deformation being dominated by differential 967 loading and salt expulsion. Conversely, the later sequences are dominated by extension and 968 movement over a large landward-dipping listric normal fault (b-f), although salt expulsion also 969 occur secondarily due to greater sediment loading on its hangingwall. During the Aptian (a) and Albian (b), the base-salt dipped regionally $>1$ 을 basinward but flipped gradually through time during the deposition of the anomalously thick post-Albian rollover within the Albian Gap.

NW

a) Aptian $2.2 \mathrm{~km}$

VE: 2

$50 \mathrm{~km}$

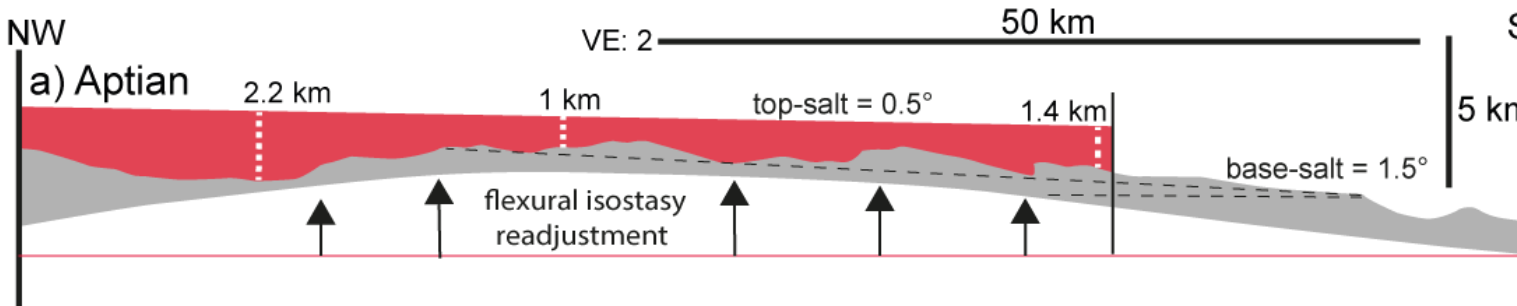

b) Albian

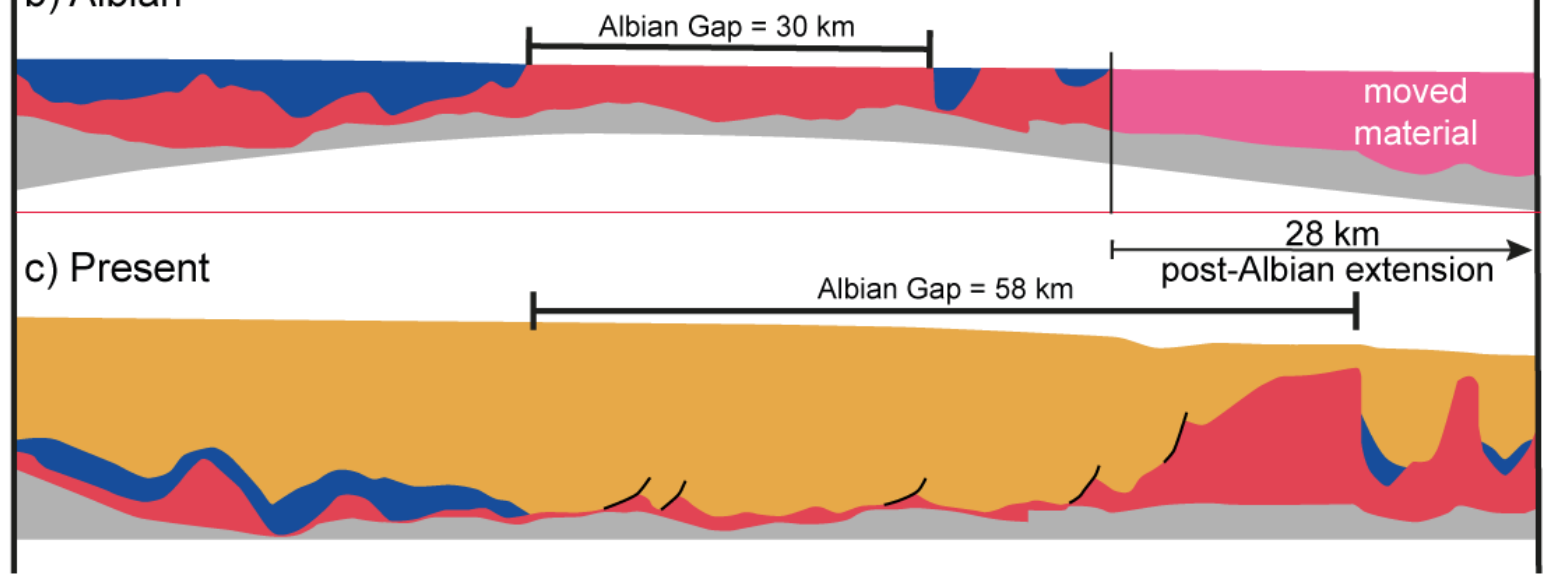

972

Figure 18: Restoration of a section over the southern portion of the Albian Gap (Fig. 7) showing dip reversal of the base-salt by flexural isostasy due to the deposition of a c. 6-7 km thick postAbian rollover (fig. 9). The Albian Gap is at present $58 \mathrm{~km}$, resulting from a combination from post-Albian extension (c. $28 \mathrm{~km}$ ) and salt expulsion from a c. $30 \mathrm{~km}$ wide Albian salt wall. 


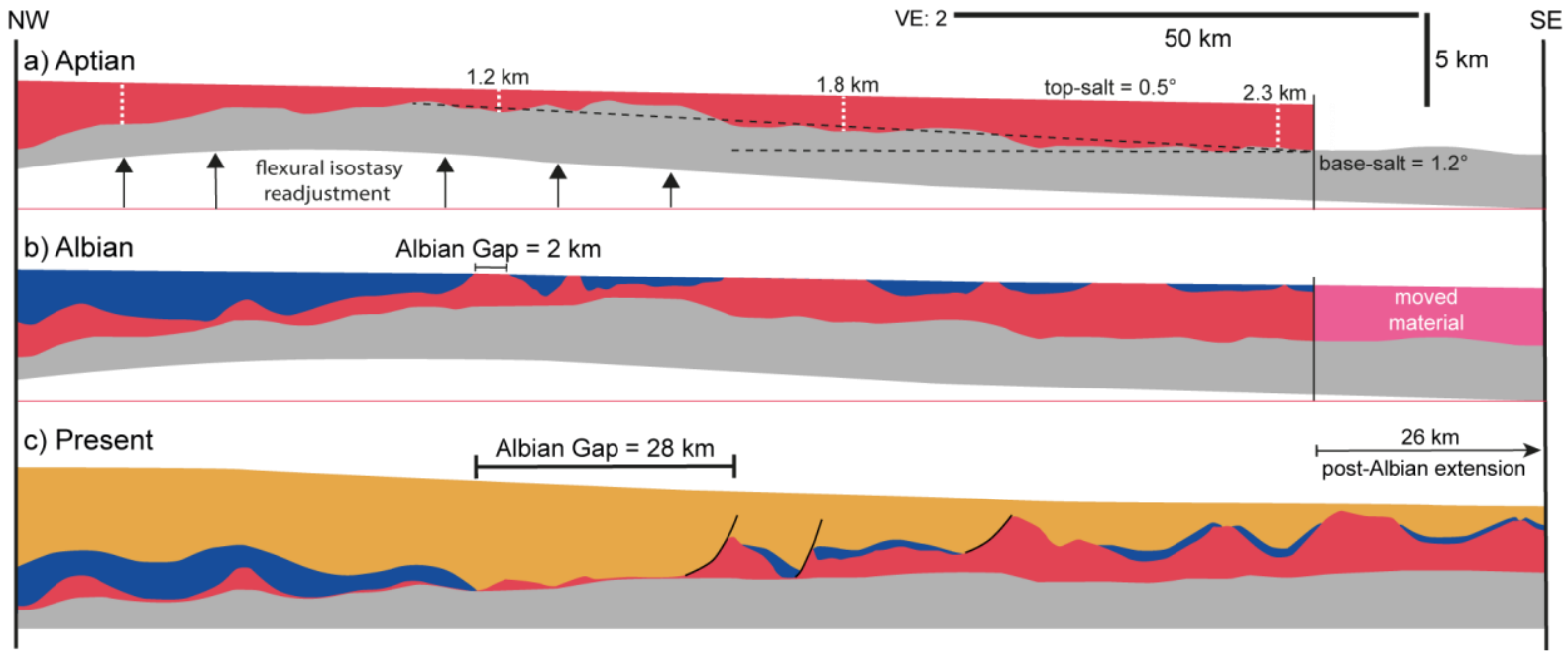

978 Figure 19: Restoration of section over the northern portion of the Albian Gap showing dip 979 reversal of the base-salt by flexural isostasy due to the deposition of a c. $5 \mathrm{~km}$ thick post-Abian 980 rollover (fig. 10). The Albian Gap is at present $28 \mathrm{~km}$, resulting primarily of post-Albian 981 extension (c. $26 \mathrm{~km}$ ). 

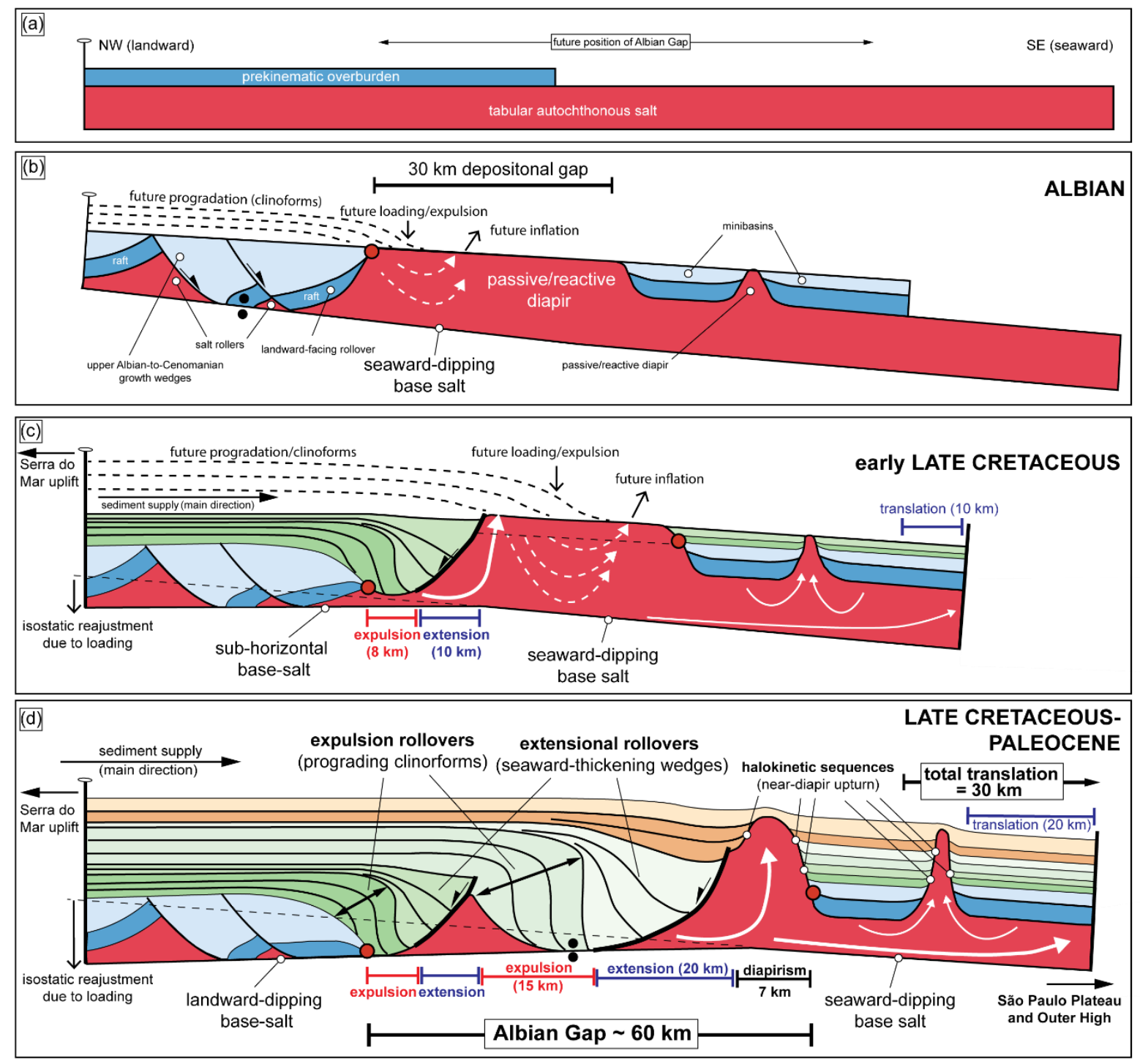

Figure 20: New kinematic model explaining the origin and evolution of the Albian Gap. (a-b)

984 During the Albian, salt deformation was controlled by salt detached extension with basinward985 dipping normal faults and development of a $30 \mathrm{~km}$ wide reactive/passive diapir downdip. (c) 986 During the early Late Cretaceous, margin-scale progradation of sediments over the earlierformed passive salt wall resulted in develop of small landward-dipping normal faults (extension) and salt expulsion (differential loading) from the diapir onto the São Paulo Plateau further downdip. (d) Continuous progradation resulted in further salt expulsion and extension with development of larger landward-dipping faults and, consequently, salt inflation, diapirism and translation further downdip. The normal faults became progressively younger basinward and larger through time as a consequence of gradual landward-rotation of the base-salt driven by base-salt isostatic readjustment in response to the greater loading within the Albian Gap. 